\title{
What Do We Know about Accounting in Family Firms?
}

\begin{abstract}
In this study, we present a review of research of accounting in family firms. The aim is to summarize the main findings of prior studies and identify what we have learned so far about the role of accounting in family firms. Specifically, we survey the contributions of accounting researchers to the study of family firms in four subfields: (1) financial accounting and reporting, (2) management accounting and management control, (3) auditing, and (4) accounting history. After considering some theoretical and empirical advancements of family business research in other disciplines, we conclude by identifying avenues for future research.
\end{abstract}

Keywords: Accounting Research; Family Firms; Financial Accounting; Management Accounting; Auditing; Accounting History; Literature Review

\section{Introduction}

Family businesses play a significant role in the economy. In the European Union (EU), they make up for more than $60 \%$ of all companies, including sole proprietors to large multinational corporations (EU 2017). In the United States (US), family firms represent close to $33 \%$ of the S\&P 500 Industrials firms and 48\% of the S\&P 1500 firms (Khalil and Mazboudi 2016).

Corresponding author: e-mail: nieves.carrera@ie.edu

Received 05 April 2017 - Accepted 21 June 2017

This is an Open Access article distributed under the terms of the Creative Commons Attribution-Non-Commercial-No Derivatives License (http://creativecommons.org/licenses/by-nc-nd/4.0/), which permits non-comercial re-use and distribution, provided the original work is properly cited, and is not altered or transformed in any way. 
Following the development of research on family business in areas such as business, management and entrepreneurship, accounting researchers have increasingly showed an interest in the accounting and reporting practices of family firms. In order to understand to what extent accounting practices of family firms differ from those of non-family firms, accounting researchers have adopted the research questions, approaches and methods used in prior research investigating non-family businesses.

If family firms "think and act differently" (Moores and Salvato 2009, 186), then we expect differences in their accounting and reporting decisions when compared to non-family businesses. Their unique characteristics include the concentrated ownership in the hands of a controlling family, the power of the controlling family to pursue their goals, the involvement of the family in the governance of the firm, and the close relationship between managers and the family (Anderson and Reeb 2003; Prencipe, Bar-Yosef, and Dekker 2014; Steier, Chrisman, and Chua 2015). Importantly, the relevance of non-economic factors such as reputation, social capital and the long-term survival for family firms is significantly higher than in the case of non-family firms (Arregle et al. 2007; Gomez-Mejia, Cruz, and Imperatore 2014).

Even though the interest of accounting researchers on family businesses is relatively new, several literature reviews have been published in the last few years with the aim to identify the dominant themes and avenues for future research (e.g., Salvato and Moores 2010; Songini, Gnan, and Malmi 2013; Prencipe et al. 2014). This study supplements these preliminary insights in several ways. First, we summarize and assess the findings of prior reviews. Second, we update the state-of-the-art of accounting research in family business by examining the papers published since 2014 to present (2017). Third, we add some insights from prior research 
in accounting history, a subfield neglected in previous reviews. Finally, we add some additional insights regarding future research.

To focus the paper, we limit the review to certain areas of accounting research ${ }^{1}$. First, we focus on financial accounting and on what we have learned so far about financial reporting quality, earnings management, disclosures and accounting choices in family firms. This is by far the most developed area in accounting and family firms. Second, we review studies on managerial accounting, with an emphasis on management accounting practices and the drivers of management accounting change in family firms. Third, we review studies examining the demand for auditing, the choice of auditor and audit fees. Finally, we discuss the contribution of accounting history research to our understanding of accounting in family firms.

The challenges of research on family firms open a number of possibilities for future work. First, from a theoretical perspective, we concur with prior research (e.g., Salvato and Moores 2010) suggesting that future studies could benefit from adopting a theoretical approach beyond the agency framework dominant in previous studies. Second, as far as the empirics is concerned, researchers should go beyond the dichotomy of family firms versus non-family firms in order to capture the heterogeneity within family firms. Researchers should be more willing to use a mix of data (e.g., archival data together with survey data or case studies) to explore the universe of family firms. Importantly, like in other research areas on family firms (e.g., see Bravo et al. 2017) qualitative approaches could provide new insights about the role of accounting in family firms.

\footnotetext{
${ }^{1}$ We do not include studies accounting information systems, corporate social responsibility and taxation. Similarly, we do not include papers in corporate governance unless they have a clear link with financial accounting research (for a review of corporate governance studies on family firms see Steier et al. (2015)).
} 
There are a number of areas in accounting research examining family firms worth exploring in future research such as the variation of accounting practices of family firms across jurisdictions, the influence of management accounting systems on succession, or auditor's judgment in the context of family firms. Finally, a historical perspective using single case studies may also help to grasp a better understanding of accounting in family businesses. We conclude by arguing that accounting scholars could benefit from adopting an interdisciplinary approach and collaborate with researchers with expertise on family firms from other areas of knowledge.

The paper is structured as follows. We first introduce accounting research and the role of accounting in family firms. In this section we comment on prior literature reviews, explain how we conducted the review and show the main results. We also briefly discuss the concept of family business. In Section 3, we examine studies related to financial reporting and provide a discussion of their main findings. In Section 4, we focus on studies on management accounting in family firms. Sections 5 and 6 focus on auditing studies and on accounting history respectively. Section 7 provides some insights for future research and Session 8 concludes.

\section{The Role of Accounting in Family Firms}

The research area of accounting comprises a broad range of areas including financial accounting, managerial accounting, auditing, taxation, governance and accounting information systems. In this paper, we focus on four main sub-disciplines in the area: financial accounting and reporting, managerial accounting, auditing and accounting history. While financial accounting deals mainly with the communication of organizations to external users such as shareholders, investors, creditors or suppliers, management accounting involves providing information to internal users, primarily managers. Research topics in the field include the quality of the financial information and the impact of accounting choices. Managerial 
accounting research topics include studies on formal and informal control systems and the decision to adopt different management control systems. Auditing, although linked to the broad area of financial accounting, is considered a separate discipline. Auditing research focuses on issues such as the demand of auditing services, the characteristics of auditors, and the pricing strategy of audit firms among other topics. Accounting history aims to understand the development of accounting practices as well as how accounting affects individuals, organizations and society over time (Walker 2009; Carnegie and Napier 2012).

\subsection{Accounting in Family Firms}

Family firms have unique characteristics that explain why we expect their accounting and accountability practices to be different from those of non-family firms. These unique characteristics include the concentrated ownership in the hands of a controlling family, the power of the controlling family to pursue their goals, the involvement of the family in the governance of the firm, the interest of the controlling family in the long-term survival of the firm, the close relationship between managers and the family, and the relevance of noneconomic factors such as reputation, the emotional attachment of the family to the business, and the "dual" social capital (firm social capital and family social capital) present in family businesses (Anderson and Reeb 2003; Villalonga and Amit 2006; Arregle et al. 2007; GomezMejia et al. 2011). These traits are key drivers of business decisions in general and of accounting decisions in particular.

\subsection{Prior Reviews of Research on Accounting in Family Firms}

In the last few years we have seen a significant increase in the number of studies exploring accounting issues within the context of family businesses. The growing interest is reflected in the special issues published on Family Business Review, Journal of Family Business Strategy 
and European Accounting Review and in the publication of several literature reviews on the topic (e.g., Bhaumik and Gregoriou 2010; Salvato and Moores 2010; Songini et al. 2013; Prencipe et al. 2014; Senftlechner and Hiebl 2015; Sousa-Paiva, Costa-Lourenço, and CasteloBranco 2016; Helsen et al. 2017). Table 1 presents a short summary of prior reviews on accounting and family firms.

Salvato and Moores (2010) develop a framework to identify the specific features of accounting practices in family firms and an agenda for future research. They find 47 articles published since the 1980s, most of them related to financial accounting (35 papers, $75 \%$ ). They identify nine $(19 \%)$ papers on auditing and three $(6 \%)$ on management accounting. Except for three papers, all are empirical and quantitative and the dominant approach was the agency theory. They develop a list of research questions in financial accounting, managerial accounting and auditing, with a suggestion of the possible approaches, methods and empirical contexts to consider. They also propose the adoption of theoretical approaches different to the dominant agency theory.

Songini et al. (2013) follow the methodology adopted by Salvato and Moores (2010) to identify the papers published in the period 2010 -2013. They identify 16 papers, half of them related to financial accounting issues such as earnings management, disclosure practices and earnings quality, and the other half to managerial accounting topics like balanced scorecard, management accounting practices and the role of the CFO. The authors conclude by arguing that the intersection between accounting and family studies has potential, particularly when it comes to managerial accounting. 


\section{Journal of Evolutionary Studies in Business}

Table 1. Articles Reviewing Accounting and Family Firms Research

\begin{tabular}{|c|c|c|c|c|c|}
\hline Study & Journal* & Field** & Data Source & Sample & Summary \\
\hline $\begin{array}{l}\text { Bhaumik and } \\
\text { Gregoriou } \\
\text { (2010) }\end{array}$ & JES & $\begin{array}{l}\text { FA } \\
\text { EM }\end{array}$ & N/A & N/A & $\begin{array}{l}\text { - Discussion of the mechanisms by which families retain control over firms and the incentives of family firms to expropriate other } \\
\text { non-family shareholders. } \\
\text { - Examination of the role of EM to facilitate tunneling } \\
\text { - Opportunities for further research: expand the research on EM in other settings and undertake cross-country comparisons. }\end{array}$ \\
\hline $\begin{array}{l}\text { Helsen et al. } \\
(2017)\end{array}$ & JES & MA & EBSCO & $\begin{array}{l}32 \text { articles, } \\
(1990-2015)\end{array}$ & $\begin{array}{l}\text { - Comprehensive review of literature on choice of management control systems (MCS) in family firms. } \\
\text { - Studies are organized in three areas: i) papers examining a specific management control tool; ii) papers examining the determinants } \\
\text { of the choice of MCS; and iii) outcomes of the choice of MCS. } \\
\text { - For each area above, discussion of the theoretical approaches, evidence and insights for future research. }\end{array}$ \\
\hline $\begin{array}{l}\text { Prencipe, Bar- } \\
\text { Yosef and } \\
\text { Dekker (2014) }\end{array}$ & EAR & $\begin{array}{l}\text { FA } \\
\text { MA } \\
\text { AU }\end{array}$ & N/A & $\begin{array}{l}37 \text { articles, } \\
(1980-2014)\end{array}$ & $\begin{array}{l}\text { - Discussion of the theoretical and empirical challenges of accounting researchers when analyzing family firms. Review of the four } \\
\text { main theoretical approaches used in family firms. Discussion of how to define "family firms". } \\
\text { - Comprehensive review of studies on accounting research in family firms. Articles classified based on: a) key issues addressed; b) } \\
\text { theoretical framework adopted; and c) operational definition of family firm. } \\
\text { - Insights and suggestions for future research. }\end{array}$ \\
\hline $\begin{array}{l}\text { Salvato and } \\
\text { Moores } \\
\text { (2010) }\end{array}$ & FBR & $\begin{array}{l}\text { FA } \\
\text { MA } \\
\text { AU }\end{array}$ & $\begin{array}{l}\text { EBSCOhost, } \\
\text { ABI/INFORM and } \\
\text { BusinessSource } \\
\text { Complete }\end{array}$ & $\begin{array}{l}47 \text { articles, } \\
(1980-2010)\end{array}$ & $\begin{array}{l}\text { - Comprehensive review of literature on accounting and family firms. Contributions in three areas: a) financial accounting, with an } \\
\text { emphasis of EM; b) management accounting; and c) auditing. } \\
\text { - Discussion of the potential extension of research in the area, with some suggestions for research questions and possible approaches, } \\
\text { methods and empirical contexts. }\end{array}$ \\
\hline $\begin{array}{l}\text { Senftlechner } \\
\text { and Hiebl } \\
\text { (2015) }\end{array}$ & JAOC & MA & $\begin{array}{l}\text { Elsevier, } \\
\text { ScienceDirect, } \\
\text { SciVersem EBSCO, } \\
\text { Business Source Elite, } \\
\text { EMERALD, SAGE } \\
\text { Journals, SpringerLink, } \\
\text { Scopus, ISI Web of } \\
\text { Knowledge }\end{array}$ & $\begin{array}{l}33 \text { articles, } \\
(1985-2012)\end{array}$ & $\begin{array}{l}\text { - Comprehensive review of empirical literature on management accounting (MA) and management control (MC) in family firms. } \\
\text { - Reviewed papers are classified based on type of article and geographical area, data collection and period, sample size and firm size } \\
\text { and informant and analytical approach. Discussion of definition of "family business". } \\
\text { - Findings of prior research are classified based on three categories: antecedents, configurations and outcomes of MA and MC. } \\
\text { - Research questions for future research about informal and formal MA and MC systems, knowledge transmission, link between } \\
\text { corporate governance and MA/MC, and changes in top executive positions and their impact on MA/MC. }\end{array}$ \\
\hline $\begin{array}{l}\text { Songini, Gnan } \\
\text { and Malmi } \\
\text { (2013) }\end{array}$ & JFBS & $\begin{array}{l}\text { FA } \\
\text { MA } \\
\text { AU }\end{array}$ & $\begin{array}{l}\text { ScienceDirect, } \\
\text { EBSCO, EMERALD }\end{array}$ & $\begin{array}{l}16 \text { articles, } \\
(2010-2013)\end{array}$ & $\begin{array}{l}\text { - Discussion of prior research around three key family business characteristics: i) involvement of the family in the management: ii) } \\
\text { ownership and governance, and iii) the socioemotional wealth and succession. } \\
\text { - Following Salvato and Moores (2010), it updates of the state-of-the-art of accounting research for the period 2010-2013. It considers } \\
\text { journals not included in the prior review. } \\
\text { - Summary of the papers included in the special issue and suggestions for future research. }\end{array}$ \\
\hline
\end{tabular}

\section{Online ISSN: 2385-7137}

http://revistes.ub.edu/index.php/JESB
COPE Committee on Publication Ethics Creative Commons License 4.0 @creative 


\section{Journal of Evolutionary Studies in Business JESB}

Volume 2, Number 2, 97-159, July-December 2017

doi:10.1344/jesb2017.2.j032

\begin{tabular}{|c|c|c|c|c|c|}
\hline Study & Journal* & Field** & Data source & Sample & Summary \\
\hline $\begin{array}{c}\text { Sousa- } \\
\text { Paiva, } \\
\text { Costa- } \\
\text { Lourenço } \\
\text { and Castelo- } \\
\text { Branco } \\
(2016)\end{array}$ & RAF & $\begin{array}{l}\text { FA } \\
\text { EM }\end{array}$ & N/A & $\begin{array}{c}17 \text { articles } \\
\text { (2006-2015) }\end{array}$ & $\begin{array}{l}\text { - Comprehensive review of literature on EM in family firms. } \\
\text { Summary of the three main theoretical frameworks used in prior studies: agency, stewardship and SEW approaches. } \\
\text { Insights for future research. }\end{array}$ \\
\hline $\begin{array}{l}\text { Trotman } \\
\text { and } \\
\text { Trotman } \\
(2010)\end{array}$ & FBR & $\mathrm{AU}$ & N/A & $\begin{array}{l}2 \text { articles on } \\
\text { auditing, } \\
(2006-2008)\end{array}$ & $\begin{array}{l}\text { - Opportunities for audit judgment and decision-making (JDM) research in family firms. Discussion about the theoretical framework } \\
\text { for Audit JDM Research. Discussion of the task, individual and individual interactions in this context. } \\
\text { - Review of some key prior studies on accounting, auditing and corporate governance of family firms. Discussion on how their } \\
\text { findings may contribute to future audit research. }\end{array}$ \\
\hline
\end{tabular}

Source: Own elaboration.

* See the list of journals and acronyms in the Appendix. WP: Working Paper.

**Field: AU (Auditing), FA (Financial Accounting), MA (Managerial Accounting), EM (Earnings Management)

\section{Online ISSN: 2385-7137}

http://revistes.ub.edu/index.php/JESB
COPE Committee on Publication Ethics

Creative Commons License 4.0 @creative 
Prencipe et al. (2014) review four theoretical frameworks widely used in family business research in management (agency framework, stewardship theory, Resource-Based View (RBV) of the firm and Socioemotional Wealth (SEW) approach) and discuss the key empirical challenge in this field: how to define and operationalize the concept of family firm. Before giving some suggestions for future research, they provide a review of the papers since the 1980s. Their search strategy is more limited than the one used by Salvato and Moores (2010) as they exclude terms such as "privately held firms" when there is no clear analysis or evidence related to family issues (Prencipe et al. 2014, 369). They identify 38 papers, 16 (42\%) were included in Salvato and Moores (2010), five (13\%) were published before 2010 but not included in Salvato and Moores (2010), and 15 (40\%) were published in the period 2010-2014.

These reviews clearly show the dominance of studies on financial accounting issues. By far, the most popular topic is financial reporting quality, especially "earnings management" (EM). Bhaumik and Gregoriou (2010) examine prior research on EM in family firms, with a focus on the mechanisms by which families retain control and their incentives to expropriate resources from non-family shareholders. Sousa-Paiva et al. (2016) also review studies contributing to this specific area (see details in Table 1). Senftlechner and Hiebl (2015) and Helsen et al. (2017) argue that prior literature reviews omit a significant number of papers on management accounting and control in family firms published in the last few years. Senftlechner and Hiebl (2015) identify 33 articles examining management accounting and control in the context of family firms for the period 1985-2012 and Helsen et al. (2017) identify 32 articles for the period 1990-2015. These reviews classified the contributions in three groups: (i) studies examining the antecedents of management accounting and control in family firms; (ii) studies analyzing the configurations of these practices; and (iii) studies focused on the outcomes of the choice of 
management accounting and controls systems. In contrast with prior reviews, Helsen et al. (2017) included papers related to compensation and human resources management (HRM) if they relate to management controls. As far as auditing research is concerned, Trotman and Trotman (2010) provide an interesting discussion about the potential theories and methods that can be used to address research questions on the audit of family firms from an audit Judgment and Decision Making (audit JDM) research perspective. To our knowledge, no previous literature review has considered the contributions of accounting history research to the area of family firms.

We complement these reviews by updating the state-of-the-art of accounting research in the area. We carried out an analysis of the papers published in the period 2014 to 2017 . To identify the studies, we consider the journals in Salvato and Moores (2010), Songini et al. (2013) and Prencipe et al. (2014) $)^{2}$. For the search strategy, we use the keywords of Salvato and Moores $(2010,195)$. This search resulted in 31 relevant articles, four of which are the literature reviews displayed in Table 1. Table 2 describes the remaining 27 papers and one article published in 2013 (Ho and Kang 2013) which, in spite of its relevance, was not included in previous reviews. We also include two working papers (WP): Cruz, Imperatore and Gomez-Mejia (2015) and Mengoli and Pazzaglia (2017). Out of the 30 papers displayed in Table 2, 16 (53\%) are related to financial accounting, five (17\%) discuss issues related to management accounting and control and nine (30\%) examine auditing issues. Most papers are empirical and adopt an agency framework.

\footnotetext{
${ }^{2}$ The list of journals included in these reviews and in our study are available in the Appendix. We acknowledge the potential bias in our results due to the omission of some journals in the search strategy.
} 


\section{Journal of Evolutionary Studies in Business}

Table 2. Reviewed Research on Accounting in Family Firms- Period 2014-2017 (excluding accounting history)

\begin{tabular}{|c|c|c|c|c|c|c|c|}
\hline Study & Journal* & Field** & Topic & Theory & Method & Sample/Case & Findings \\
\hline $\begin{array}{l}\text { Achleitner, Günther, } \\
\text { Kaserer and } \\
\text { Siciliano (2014) }\end{array}$ & EAR & FA & $\begin{array}{l}\text { Earnings } \\
\text { Management }\end{array}$ & SEW & Empirical & $\begin{array}{l}838 \text { firms, } \\
\text { Germany }\end{array}$ & $\begin{array}{l}\text { Family firms engage less in real EM and exhibit more earnings-decreasing accruals-based } \\
\text { EM than non-family firms. Family firms treat these two types of EM as substitutes; non- } \\
\text { family firms, however, treat them more as complementary tools for EM. }\end{array}$ \\
\hline $\begin{array}{l}\text { Bardhan, } \mathrm{Li} \text { and } \mathrm{Wu} \\
\text { (2015) }\end{array}$ & $\mathrm{AH}$ & FA & Internal controls & Agency & Empirical & S\&P 500 & $\begin{array}{l}\text { Family firms exhibit more material weaknesses in their internal control over financial } \\
\text { reporting than non-family firms. The greater likelihood of material weaknesses is driven by } \\
\text { family firms with dual-class shares. Results consistent with the entrenchment hypothesis that } \\
\text { family owners are motivated to maintain weaker internal controls to extract private benefits. }\end{array}$ \\
\hline $\begin{array}{l}\text { Barroso, Ali and } \\
\text { Lesage (2016) }\end{array}$ & EAR & $\mathrm{AU}$ & Audit fees & Agency & Empirical & $\begin{array}{l}7982 \text { firm-year } \\
\text { observation from } \\
19 \text { countries }\end{array}$ & $\begin{array}{l}\text { There is a U-shaped relation between blockholder ownership and audit fees in the shareholder } \\
\text { corporate governance model; and an inverted U-shaped relation between blockholder } \\
\text { ownership and audit fees in the stakeholder corporate governance model. The results hold } \\
\text { when considering family firms, which suggest that the importance of the context goes beyond } \\
\text { firm characteristics. }\end{array}$ \\
\hline $\begin{array}{l}\text { Cesaroni and Sentuti } \\
\text { (2017) }\end{array}$ & JFBM & MA & Role of Accountants & & $\begin{array}{l}\text { Empirical. } \\
\text { Survey. }\end{array}$ & 175 auditors, Italy & $\begin{array}{l}\text { Accountants are mostly concerned with technical elements/solutions and less careful about } \\
\text { relations and communication between family members. They underestimate the relevance of } \\
\text { the ability to empathize with the family. This may cause a discrepancy between family firm } \\
\text { expectations and accountant's professional practice. }\end{array}$ \\
\hline $\begin{array}{l}\text { Chen, Chen and } \\
\text { Cheng (2014) }\end{array}$ & EAR & FA & Conservatism & Agency & Empirical & S\&P 1500 & $\begin{array}{l}\text { Conservatism increases with non-CEO family ownership (family owners have the incentives } \\
\text { and the ability to implement conservative financial reporting to reduce legal liability and } \\
\text { mitigate agency conflicts). This relationship is not significant in family firms with founders } \\
\text { serving as CEOs. }\end{array}$ \\
\hline $\begin{array}{l}\text { Chen, Ding, Wu and } \\
\text { Yang (2016) }\end{array}$ & JSBM & FA & $\begin{array}{l}\text { Change in } \\
\text { accounting } \\
\text { regulation }\end{array}$ & Agency & Empirical & $\begin{array}{l}6950 \text { firms from } \\
80 \text { countries }\end{array}$ & $\begin{array}{l}\text { In the transition to International Accounting Standards (IAS), family firms tend not to } \\
\text { voluntarily switch from local GAAP to IAS. IAS adoption differentially influences private } \\
\text { firms, family firms versus non-family firms, in terms of their access to debt capital. }\end{array}$ \\
\hline $\begin{array}{l}\text { Collin, Ahlberg, } \\
\text { Berg, Broberg and } \\
\text { Karlsson (2017) }\end{array}$ & JFBM & $\mathrm{AU}$ & Role of auditors & & $\begin{array}{l}\text { Empirical. } \\
\text { Survey }\end{array}$ & $\begin{array}{l}309 \text { auditors. } \\
\text { Sweden }\end{array}$ & $\begin{array}{l}\text { In family firms, auditors primarily perform the monitoring role of the audit. However, there } \\
\text { are indications of the auditor performing the consigliere role, through performing the } \\
\text { advisory and mediating functions and, to a smaller degree, the conveying function. }\end{array}$ \\
\hline $\begin{array}{l}\text { Corten, Steijvers } \\
\text { and Lybaert (2015) }\end{array}$ & $\mathrm{ABR}$ & $\mathrm{AU}$ & Demand of auditing & Agency & Empirical & 482 firms, US & $\begin{array}{l}\text { Reviews/compilations done by auditors seem to be sufficient and more cost-effective in the } \\
\text { context of family firms to mitigate Type I agency costs compared to audits. The level of } \\
\text { shareholder-debtholder agency costs seems to be a driver for the demand for audits. }\end{array}$ \\
\hline
\end{tabular}

\section{Online ISSN: 2385-7137}

http://revistes.ub.edu/index.php/JESB
COPE Committee on Publication Ethics Creative Commons License 4.0 @ccreative 


\section{Journal of Evolutionary Studies in Business}

\begin{tabular}{|c|c|c|c|c|c|c|c|}
\hline Study & Journal* & Field $* *$ & Topic & Theory & Method & Sample/Case & Findings \\
\hline $\begin{array}{l}\text { Corten, Steijvers } \\
\text { and Lybaert (2017) }\end{array}$ & JFBS & $\mathrm{AU}$ & Demand of auditing & Agency & $\begin{array}{l}\text { Empirical. } \\
\text { Questionnaire }\end{array}$ & $\begin{array}{l}125 \text { firms, } \\
\text { Belgium }\end{array}$ & $\begin{array}{l}\text { High quality auditors are hired by family firms to mitigate agency conflicts. Monitoring } \\
\text { effectiveness of the board weakens the association between the level of intra-family agency } \\
\text { conflicts and audit (quality) demand. The audit demand effect caused by intra-family agency } \\
\text { conflicts decreases when the firm is able to reduce the agency costs internally. }\end{array}$ \\
\hline $\begin{array}{l}\text { Cruz, Imperatore } \\
\text { and Gomez-Mejia } \\
\text { (2015) }\end{array}$ & WP & FA & $\begin{array}{l}\text { Earnings } \\
\text { management }\end{array}$ & SEW & Empirical & European firms. & $\begin{array}{l}\text { Family firms are less likely to smooth earnings as capital market conditions deteriorate } \\
\text { compared to non-family firms. Family firms are less likely to opportunistically smooth } \\
\text { earnings as financial crisis increases. }\end{array}$ \\
\hline $\begin{array}{l}\text { Dekker, Lybaert, } \\
\text { Steijvers and } \\
\text { Depaire (2015) }\end{array}$ & JSBM & MA & Professionalization & Agency & Empirical & $\begin{array}{l}523 \text { firms, } \\
\text { Belgium }\end{array}$ & $\begin{array}{l}\text { No evidence of a significant relationship between the use of formal financial controls and } \\
\text { firm performance. However, the use of HRM control systems has a positive impact on } \\
\text { financial performance. }\end{array}$ \\
\hline $\begin{array}{l}\text { Effering and } \\
\text { Hartono (2015) }\end{array}$ & JAOC & MA & $\begin{array}{l}\text { Management control } \\
\text { practices and } \\
\text { leadership }\end{array}$ & & Case study & $\begin{array}{l}\text { Indonesian } \\
\text { company. }\end{array}$ & $\begin{array}{l}\text { Leadership and the management control system (MCS) of family firms are embedded in its } \\
\text { societal culture. The owner and his/her circle may play crucial roles in producing and } \\
\text { reproducing the legitimate MCS based on the extended family concept. Cultural control based } \\
\text { on shared family norms is the most dominant one and simplifies process and result controls. }\end{array}$ \\
\hline $\begin{array}{l}\text { Ghosh and Tang } \\
\text { (2015) }\end{array}$ & JAE & $\mathrm{AU}$ & $\begin{array}{l}\text { Audit fees. Financial } \\
\text { reporting quality }\end{array}$ & Agency & Empirical & $\begin{array}{l}2000 \text { largest } \\
\text { industrial firms, } \\
\text { US }\end{array}$ & $\begin{array}{l}\text { Auditors charge family firms significantly less fees, and the fee difference shrinks in } \\
\text { magnitude when family firms have high audit risk. Overall, family firms have lower audit } \\
\text { risk and their auditors work less to provide assurance. These results are consistent with family } \\
\text { firms having superior reporting quality that lowers audit risk. }\end{array}$ \\
\hline $\begin{array}{l}\text { Golden and } \\
\text { Kohlbeck (2017) }\end{array}$ & AA & FA & $\begin{array}{l}\text { Voluntary } \\
\text { Disclosures. } \\
\text { Compensation }\end{array}$ & Agency & Empirical & S\&P 1500 & $\begin{array}{l}\text { Family firms are less likely to provide management earnings forecasts when their CEO's } \\
\text { wealth is higher in contrast with non-family firms. The main result holds when a family } \\
\text { member serves as CEO or on the board of directors. }\end{array}$ \\
\hline $\begin{array}{l}\text { Gomez-Mejia, Cruz } \\
\text { and Imperatore } \\
\text { (2014) }\end{array}$ & EAR & FA & $\begin{array}{l}\text { Financial Reporting } \\
\text { Quality }\end{array}$ & SEW & Conceptual & & $\begin{array}{l}\text { Integrated framework to financial reporting decisions in family firms based on the SEW } \\
\text { theory. Several propositions regarding the probability of the firms to engage EM and to } \\
\text { produce voluntary disclosures depending on two dimensions of SEW: "family control and } \\
\text { influence" and "family identification". }\end{array}$ \\
\hline $\begin{array}{l}\text { Greco, Ferramosca } \\
\text { and Allegrini (2015) }\end{array}$ & FBR & FA & $\begin{array}{l}\text { Accounting } \\
\text { Decisions }\end{array}$ & Agency & Empirical & 142 firms, Italy & $\begin{array}{l}\text { Family firms use write-offs in a way that is consistent with performance. Non-family firms, } \\
\text { however, use write-offs for EM purposes. This result is consistent with reduced Type I } \\
\text { agency conflict in the case of family firms as compared to non-family firms. There is no } \\
\text { evidence of family entrenchment (i.e., family owners being concerned with the reputational } \\
\text { damage associated with a decrease in assets' value). }\end{array}$ \\
\hline $\begin{array}{l}\text { Ho and Kang (2013) } \\
\text { (a) }\end{array}$ & AJPT & $\mathrm{AU}$ & $\begin{array}{l}\text { Auditor choice. } \\
\text { Audit fees }\end{array}$ & Agency & Empirical & S\&P 1500 & $\begin{array}{l}\text { Family firms are less likely to hire top-tier auditors and incur in lower audit fees than non- } \\
\text { family firms. The tendency of family firms to hire non-top-tier auditors and to pay lower } \\
\text { audit fees is stronger when family owners actively monitor their firms. }\end{array}$ \\
\hline
\end{tabular}

\section{Online ISSN: 2385-7137}

http://revistes.ub.edu/index.php/JESB
COPE Committee on Publication Ethics Creative Commons License 4.0 @ creative 


\section{Journal of Evolutionary Studies in Business}

\begin{tabular}{|c|c|c|c|c|c|c|c|}
\hline Study & Journal* & Field** & Topic & Theory & Method & Sample/Case & Findings \\
\hline $\begin{array}{l}\text { Jara-Bertin and } \\
\text { López-Iturriaga } \\
\text { (2014) }\end{array}$ & SJAF & FA & $\begin{array}{l}\text { Earnings } \\
\text { management (EM) }\end{array}$ & Agency & Empirical & $\begin{array}{l}3559 \text { listed firms } \\
\text { from Canada, } \\
\text { France, Italy, } \\
\text { Spain, UK, US }\end{array}$ & $\begin{array}{l}\text { The contest to the dominant family shareholder is relevant for EM: in family firms, the more } \\
\text { challenge to the control of dominant shareholders, the less EM. This contest is more } \\
\text { important in civil law countries where shareholders' rights are less protected. Consistent with } \\
\text { the view that non-family shareholders are under more public scrutiny and have more } \\
\text { difficulty to agree with the largest family shareholder, a second or third non-family } \\
\text { shareholder can reduce or alleviate EM. }\end{array}$ \\
\hline Kang (2014) & $\mathrm{AH}$ & $\mathrm{AU}$ & Auditor choice & Agency & Empirical & S\&P 1500 & $\begin{array}{l}\text { Family firms are more likely to appoint industry-specialist auditors than non-family firms. } \\
\text { Family firms with a family member acting as CEO or with dual-class shares have even a } \\
\text { higher tendency to hire industry specialist auditors (entrenchment argument). }\end{array}$ \\
\hline $\begin{array}{l}\text { Khalil and } \\
\text { Mazboudi (2016) }\end{array}$ & AJPT & $\mathrm{AU}$ & $\begin{array}{l}\text { Client's acceptance. } \\
\text { Audit fees }\end{array}$ & Agency & Empirical & $\begin{array}{l}562 \text { firm-year } \\
\text { observations, US }\end{array}$ & $\begin{array}{l}\text { Big } 4 \text { auditors perceive family firms from which the incumbent auditors resigned as being } \\
\text { less risky than their non-family firms' counterparts. They are also more likely to serve as } \\
\text { successor auditors following auditor resignations in family firms as opposed to non-family } \\
\text { firms. The changes in audit fees following the resignations in family firms are significantly } \\
\text { smaller than those in non-family firms after controlling for several factors. The likelihood of } \\
\text { financial restatements in family firms in the post-resignation period is significantly lower } \\
\text { than in non-family firms. }\end{array}$ \\
\hline $\begin{array}{l}\text { Ma, Ma and Tian } \\
\text { (2017) }\end{array}$ & EAR & FA & Corporate opacity & Agency & Empirical & 705 firms, China & $\begin{array}{l}\text { Family control is associated with a lower cost of debt on average and a negative impact exists } \\
\text { mainly in firms with relatively low corporate opacity. The moderating effect of corporate } \\
\text { opacity becomes more pronounced when investors' perception of controlling families' moral } \\
\text { hazard of expropriation is higher. }\end{array}$ \\
\hline $\begin{array}{l}\text { Mengoli and } \\
\text { Pazzaglia (2017) }\end{array}$ & WP & FA & $\begin{array}{l}\text { Financial reporting } \\
\text { quality }\end{array}$ & $\begin{array}{l}\text { Institutio } \\
\text { nal and } \\
\text { Agency }\end{array}$ & Empirical & $\begin{array}{l}22,335 \text { firms from } \\
12 \text { European } \\
\text { countries }\end{array}$ & $\begin{array}{l}\text { The institutional development of a country influences the association between family } \\
\text { ownership and reporting quality. Well-developed formal institutions have a more beneficial } \\
\text { effect on the earnings quality of non-family firms than that of family firms. Informal } \\
\text { institutions (families) have a positive influence on firm behavior in countries where formal } \\
\text { institutions are lacking. }\end{array}$ \\
\hline $\begin{array}{l}\text { Martin, Tochman- } \\
\text { Campbell and } \\
\text { Gomez-Mejia } \\
\text { (2016) }\end{array}$ & JBE & FA & $\begin{array}{l}\text { Earnings } \\
\text { management (EM) }\end{array}$ & $\begin{array}{l}\text { SEW and } \\
\text { Agency }\end{array}$ & Empirical & S\&P 500 & $\begin{array}{l}\text { Founder family firms are less likely than non-founder family firms to use EM. The effect } \\
\text { varies with the firm size, the degree of CEO entrenchment and the stock structure of the firm. }\end{array}$ \\
\hline $\begin{array}{l}\text { Martínez-Ferrero, } \\
\text { Rodríguez-Ariza } \\
\text { and Bermejo- } \\
\text { Sánchez (2015) }\end{array}$ & JFBM & FA & $\begin{array}{l}\text { Discretionary } \\
\text { practices }\end{array}$ & Agency & Empirical & $\begin{array}{l}1275 \text { non- } \\
\text { financial listed } \\
\text { companies from } \\
20 \text { countries }\end{array}$ & $\begin{array}{l}\text { Family ownership is associated with greater control and monitoring of managerial decisions, } \\
\text { thus avoiding information asymmetries. Family owners impose a stronger discipline and } \\
\text { dissuade non-family managers from using managerial discretion to act in their own interest. }\end{array}$ \\
\hline
\end{tabular}

\section{Online ISSN: 2385-7137}

http://revistes.ub.edu/index.php/JESB
COPE Committee on Publication Ethics Creative Commons License 4.0 @creative 


\section{Journal of Evolutionary Studies in Business}

\begin{tabular}{|c|c|c|c|c|c|c|c|}
\hline Study & Journal* & Field** & Topic & Theory & Method & Sample/Case & Findings \\
\hline $\begin{array}{l}\text { Muttakin, Khan and } \\
\text { Belal (2015) }\end{array}$ & AA & FA & $\begin{array}{l}\text { Disclosures of } \\
\text { intellectual capital }\end{array}$ & Agency & Empirical & $\begin{array}{l}135 \text { firms, } \\
\text { Bangladesh }\end{array}$ & $\begin{array}{l}\text { There is a non-linear relationship between family ownership and disclosures of intellectual } \\
\text { capital. Family duality (i.e., when the CEO and chairperson's position are occupied by } \\
\text { individuals of the same family) is negatively associated with the extent of such disclosures. }\end{array}$ \\
\hline $\begin{array}{l}\text { Nagar and Sen } \\
\text { (2016) }\end{array}$ & CGIR & FA & $\begin{array}{l}\text { Accounting } \\
\text { decisions }\end{array}$ & Agency & Empirical & $\begin{array}{l}15,347 \text { firm-year } \\
\text { observations, } \\
\text { India; } 14,729 \\
\text { firm-year } \\
\text { observations, US }\end{array}$ & $\begin{array}{l}\text { Family ownership has different effect on the quality of cash flow reporting in different } \\
\text { countries and country-level regulation moderates these effects differently. Cash flow } \\
\text { manipulation through classification shifting i) occurs in India and US, although it is stronger } \\
\text { in the US; ii) in India it is stronger for family firms than for non-family firms; iii) it increased } \\
\text { in India after changes in corporate governance regulation; and iv) has decreased (increased) } \\
\text { for non-family firms after regulation in India (US) along with an increase of increase } \\
\text { (decrease) of external financing. }\end{array}$ \\
\hline $\begin{array}{l}\text { Samuelsson, } \\
\text { Andersén, } \\
\text { Ljungkvist and } \\
\text { Jansson (2016) }\end{array}$ & JSMED & MA & Planning & & $\begin{array}{l}\text { Empirical. } \\
\text { Questionnaire }\end{array}$ & $\begin{array}{l}156 \text { firms, } \\
\text { Sweden }\end{array}$ & $\begin{array}{l}\text { Family firms use less formal planning than non-family firms. The results show a strongly } \\
\text { positive relationship between entrepreneurial orientation and the use of formal short-term } \\
\text { planning and long-term planning. }\end{array}$ \\
\hline $\begin{array}{l}\text { Songini and Gnan } \\
\text { (2015) }\end{array}$ & JSBM & MA & $\begin{array}{l}\text { Management } \\
\text { controls }\end{array}$ & Agency & Empirical & 146 firms, Italy & $\begin{array}{l}\text { The involvement of the family in the management is positively related to agency cost control } \\
\text { systems. Family involvement in governance, however, is negatively related to agency cost } \\
\text { control systems. The use of these mechanisms affect firm performance. }\end{array}$ \\
\hline $\begin{array}{l}\text { Srinidhi, He and } \\
\text { Firth (2014) }\end{array}$ & TAR & $\mathrm{AU}$ & $\begin{array}{l}\text { Financial reporting } \\
\text { quality. Audit } \\
\text { specialization. }\end{array}$ & Agency & Empirical & $\begin{array}{l}\text { 13,899 firm-years } \\
\text { observations, US }\end{array}$ & $\begin{array}{l}\text { Strongly governed family firms are more likely to choose specialist auditors and exhibit } \\
\text { higher earnings quality than a) non-family firms and b) other family firms. Weakly governed } \\
\text { family firms demand lower audit effort, exhibit earnings quality (no different from non- } \\
\text { family firms. Evidence that strong board governance can effectively mitigate the adverse } \\
\text { consequences of the Type II agency problems on financial reporting in family firms. }\end{array}$ \\
\hline Weiss (2014) & EAR & FA & $\begin{array}{l}\text { Financial reporting } \\
\text { quality. Internal } \\
\text { controls }\end{array}$ & Agency & Empirical & $\begin{array}{l}324 \text { listed firms, } \\
\text { Israel }\end{array}$ & $\begin{array}{l}\text { Family ownership is associated with less material weaknesses in internal controls. } \\
\text { Material weakness in internal controls in family owned firms are associated with lower } \\
\text { earnings quality than in the case of non-family firms. Investors react more negatively to } \\
\text { material weaknesses in internal controls of family firms than non-family firms. }\end{array}$ \\
\hline
\end{tabular}

Source: Own elaboration.

* See the list of journals and acronyms in the Appendix. WP: Working Paper

**Field: AU (Auditing), FA (Financial Accounting), MA (Managerial Accounting)

(a) This paper published in 2013 is included because it was not included in the previous reviews.

\section{Online ISSN: 2385-7137}

http://revistes.ub.edu/index.php/JESB
COPE Committee on Publication Ethics Creative Commons License 4.0 @ccreative 
We complement the search by considering the contributions in the field of accounting history.

For that purpose, we add to the list of journals described above several mainstream accounting journals where accounting historians publish their work (Abacus, Accounting and Business Research, and Accounting, Auditing and Accountability Journal) as well as specialist journals in accounting history (Accounting, Business and Financial History, Accounting Historians Journal, Accounting History and Accounting History Review). The search resulted in 10 papers summarized in Table 3.

\subsection{Defining Family Firms}

A key challenge in family business research is to define what exactly constitutes a "family firm" (Astrachan, Klein and Smyrnios 2002; Sharma 2004; Diéguez-Soto, López-Delgado and RojoMartínez 2015). The lack of a general definition, together with the variety of operational definitions adopted in prior studies, may explain the absence of conclusive results regarding the differences between family and nonfamily firms reported in prior research (Casillas et al. 2015; Diéguez-Soto et al. 2015).

The study "Overview of Family Business. Relevant Issues", conducted on behalf of the European Commission (EC), reviewed the definitions of "family business" in 33 countries and found 90 different definitions (KMU Forschung Austria 2008). Based on the results of this study, the EC proposes the following definition for family business:

"A firm, of any size, is a family business, if: (1) The majority of decision-making rights is in the possession of the natural person(s) who established the firm, or in the possession of the natural person(s) who has/have acquired the share capital of the firm, or in the possession of their spouses, parents, child or children's direct heirs. (2) The majority of decision-making rights are indirect or direct. (3) At least one representative of the family or kin is formally involved in the governance of the firm. (4) Listed companies meet the definition of family enterprise if the person who established or acquired the firm (share capital) or their families or descendants possess 25 per cent of the decision-making rights mandated by their share capital." (EC 2009, 10). 


\section{Journal of Evolutionary Studies in Business}

Table 3. Research on Accounting History and Family Firms

\begin{tabular}{|c|c|c|c|c|c|c|c|}
\hline Study & Journal* & Field** & Topic & Theory & Method & Sample/Case & Findings \\
\hline $\begin{array}{l}\text { Álvarez-Dardet and } \\
\text { Capelo (2003) }\end{array}$ & AHIS & $\mathrm{AH}$ & Accounting change & $\begin{array}{l}\text { Relational } \\
\text { contracts } \\
\text { theory }\end{array}$ & Case study & $\begin{array}{l}\text { Almacenes Agüera. } \\
\text { Spain. 1770-1835 }\end{array}$ & $\begin{array}{l}\text { Accounting change is driven by internal factors (e.g., the separation between ownership } \\
\text { and management and others changes of the contractual relationships within the firm) and } \\
\text { external factors (e.g., the general level of economic activity and government legislation). } \\
\text { Caution about the interpretation of concepts such as opportunism and morality today } \\
\text { versus their meaning in the } 19^{\text {th }} \text { century. }\end{array}$ \\
\hline $\begin{array}{l}\text { Baños-Sanchez } \\
\text { Matamoros, Araujo- } \\
\text { Pinzón and Alvarez- } \\
\text { Dardet Espejo } \\
\text { (2014) }\end{array}$ & SJAC & $\begin{array}{l}\mathrm{AH} \\
\mathrm{MA}\end{array}$ & $\begin{array}{l}\text { Management } \\
\text { accounting change }\end{array}$ & $\begin{array}{l}\text { Institutional } \\
\text { entrepreneu } \\
\text { rship }\end{array}$ & Case study & $\begin{array}{l}\text { Medina Garvey. Spain. } \\
1904-1969\end{array}$ & $\begin{array}{l}\text { Management accounting change drivers are strongly influenced by actors' interest and by } \\
\text { the perception and interpretation that actors make about institutional contradictions or } \\
\text { external critical events and their effects. Both process and content of accounting change } \\
\text { are shaped by the normative influences to which the actors are subject to. }\end{array}$ \\
\hline $\begin{array}{l}\text { Camfferman and } \\
\text { Zeff (2003) }\end{array}$ & ABFJ & $\begin{array}{l}\mathrm{AH} \\
\mathrm{FA}\end{array}$ & $\begin{array}{l}\text { Innovation in } \\
\text { financial reporting } \\
\text { practices }\end{array}$ & & Case study & $\begin{array}{l}\text { Unilever. Britain. } \\
1920-1947\end{array}$ & $\begin{array}{l}\text { Unilever and its top executives were considered a "retarding factor in the modernization } \\
\text { of financial reporting" in Britain, in relation to its role in the deliberations previous to the } \\
\text { approval of the Companies Act 1947. The paper aims to rehabilitate the image of the } \\
\text { company. It shows that Unilever's top executives were already considering consolidated } \\
\text { financial reporting and other innovative financial reporting practices during the 1930s } \\
\text { and 1940s. These changes coincided with the transformation of the company from a } \\
\text { family-dominated firm into a professionally managed organization. }\end{array}$ \\
\hline $\begin{array}{l}\text { Fournès-Datin } \\
\text { (2014) }\end{array}$ & AHIS & $\begin{array}{l}\mathrm{AH} \\
\mathrm{AU}\end{array}$ & Statutory audit & & Case study & $\begin{array}{l}\text { Pont-a-Mousson and } \\
\text { Saint-Gobain. France. } \\
\text { 1867-1935 }\end{array}$ & $\begin{array}{l}\text { The impact of the Company Act of July } 1867 \text { requiring statutory audit for French limited } \\
\text { companies is illustrated by examining two companies: a family firm (personal } \\
\text { capitalism) and a managerial firm. In spite of the differences in the governance and } \\
\text { capital structure of the two companies, in both cases the auditor was considered above all } \\
\text { "the right-hand man" of the board, playing the role of advisers to the board, and working } \\
\text { very closely with directors. }\end{array}$ \\
\hline $\begin{array}{l}\text { Kininmonth and } \\
\text { Mckinstry (2007) }\end{array}$ & AHIS & $\begin{array}{l}\text { AH } \\
\text { FA } \\
\text { MA }\end{array}$ & $\begin{array}{l}\text { Role of accounting } \\
\text { information. } \\
\text { Organizational } \\
\text { failure/survival. }\end{array}$ & $\begin{array}{l}\text { Revisiting } \\
\text { Chandler's } \\
\text { theory of } \\
\text { the firm. }\end{array}$ & Case study & $\begin{array}{l}\mathrm{J} \text { \& P Coats Ltd. } \\
\text { Britain. 1890-1960 }\end{array}$ & $\begin{array}{l}\text { The evidence shows that consolidation accounting, the control and funding of } \\
\text { subsidiaries, the private and confidential ledgers kept by the company and the } \\
\text { management accounting practices contributed to organizational control. Discussion of } \\
\text { Chandler's arguments regarding the role of accounting and finance in the success and } \\
\text { failure of companies. }\end{array}$ \\
\hline
\end{tabular}

\section{Online ISSN: 2385-7137}

http://revistes.ub.edu/index.php/JESB
COPE Committee on Publication Ethics Creative Commons License 4.0 @creative 


\section{Journal of Evolutionary Studies in Business}

\begin{tabular}{|c|c|c|c|c|c|c|c|}
\hline Study & Journal* & $\begin{array}{c}\text { Field } \\
* *\end{array}$ & Topic & Theory & Method & Sample/Case & Findings \\
\hline Matthew (2006) & AHIS & $\begin{array}{l}\mathrm{AH} \\
\mathrm{AU}\end{array}$ & $\begin{array}{l}\text { Development of audit } \\
\text { techniques }\end{array}$ & & $\begin{array}{l}\text { Archival } \\
\text { study }\end{array}$ & N/A & $\begin{array}{l}\text { The features of auditing techniques before 1960s were appropriate for the typical audit } \\
\text { clients: family firms. Auditors more like advisors for the accounting. Family control of } \\
\text { largest manufacturers declined from } 50 \% \text { in } 1950 \text { to } 30 \% \text { in 1970: significant impact on } \\
\text { audit procedures. The decline of family control and professionalization of management } \\
\text { explains changes in auditing procedures in the 1960s. Significant changes in the 1980s } \\
\text { due to the use of concepts such as risk assessments or analytical reviews. }\end{array}$ \\
\hline McWatters (2002) & AHJ & $\begin{array}{l}\text { AH } \\
\text { FA } \\
\text { MA }\end{array}$ & $\begin{array}{l}\text { Role of accounting } \\
\text { information. } \\
\text { Organizational failure }\end{array}$ & $\begin{array}{l}\text { Boyce' } \\
\text { thesis based } \\
\text { on the } \\
\text { agency } \\
\text { framework }\end{array}$ & Case study & $\begin{array}{l}\text { Kingston Shipping } \\
\text { Company Limited. } \\
\text { Canada. }\end{array}$ & $\begin{array}{l}\text { The accounting of the system reported and accounted for the operations of the company } \\
\text { producing standardized information. But there were important shortcomings in the } \\
\text { accounting information, which negatively impact on managerial decisions by creating the } \\
\text { "accounting reality". It is also highlighted that the role of accounting records in business } \\
\text { history research must be underscored because accounting records are prepared within a } \\
\text { specific organizational context. }\end{array}$ \\
\hline Popp (2000) & $\mathrm{ABFJ}$ & $\begin{array}{l}\mathrm{AH} \\
\mathrm{AU}\end{array}$ & Role of Auditors & & Case study & $\begin{array}{l}\text { Mintons Ltd. UK. } \\
1870-1900\end{array}$ & $\begin{array}{l}\text { The paper argues that a "signaling strategy" may be behind the motivations of a family } \\
\text { business like Mintons to hire professional ("elite") external auditors. Auditors act more } \\
\text { advisors than independent reviewers, giving strategic business advice beyond accounting } \\
\text { issues -and auditors' advices were sometimes rejected. }\end{array}$ \\
\hline $\begin{array}{l}\text { Robb, Shanahan and } \\
\text { Lord (2006) }\end{array}$ & AHIS & $\mathrm{AH}$ & Professionalization & Agency & Case study & $\begin{array}{l}\text { Ernest Adams Ltd. } \\
\text { New Zealand. 1921- } \\
1999\end{array}$ & $\begin{array}{l}\text { The paper provides evidence of the changes experienced by a family firm, through } \\
\text { restructuring under outside professional management, until being taken over by a } \\
\text { multinational company. }\end{array}$ \\
\hline $\begin{array}{l}\text { Vent and Milne } \\
(2000)\end{array}$ & ABFJ & $\begin{array}{l}\mathrm{AH} \\
\mathrm{MA}\end{array}$ & $\begin{array}{l}\text { Cost accounting } \\
\text { procedures }\end{array}$ & & Case study & $\begin{array}{l}\text { St. Joseph Lead } \\
\text { Company. US. } 1864- \\
1900 .\end{array}$ & $\begin{array}{l}\text { In spite of being the most successful and important lead-mining company in American } \\
\text { history, the company did not adopt a system of cost accounts until late in the nineteenth } \\
\text { century (later than other companies). Close association of industrial accounts and the } \\
\text { double-entry bookkeeping system, as in other mining companies in the UK. }\end{array}$ \\
\hline
\end{tabular}

Source: Own elaboration.

* See the list of journals and acronyms in the Appendix.

**Field: AU (Auditing), FA (Financial Accounting), MA (Managerial Accounting).

\section{Online ISSN: 2385-7137}

http://revistes.ub.edu/index.php/JESB
COPE Committee on Publication Ethics Creative Commons License 4.0 @creative 
From an empirical perspective, the challenge is how to operationalize a given definition of family business. The focus of most prior research has been to identify the characteristics of family firms so that they can be distinguished from non-family firms (Chua, Chrisman and Sharma 1999; Sharma 2004; Chua et al. 2012). However, more and more researchers have recognized the necessity of exploring the heterogeneity of family firms (Wright and Kellermanns 2011; Chua et al. 2012)33.

Most operational definitions emphasize the involvement of the family firm in the business. From this perspective, family involvement is a sufficient condition to make a firm a family business -the components-of-involvement approach (Chrisman, Chua and Sharma 2005, 556). This has been the dominant approach in accounting studies, which typically have adopted dichotomous variables based on proxies for family involvement such as "percentage of ownership of the family" (e.g., Mengoli and Pazzaglia 2017), "family members' involvement on top management and/or board" (e.g., Chen, Chen and Cheng 2014) or a combination of ownership and management/control indicators (e.g., Cascino et al. 2010; Martin, TochmanCampbell and Gomez-Mejia 2016) to identify family and non-family firms. This approach has been criticized because it does not take into account the goals of family firms and how their views may change over time (Chrisman et al. 2005). To overcome these limitations, researchers have focused on the "essence" of family firms (the essence approach) which aims to take into account factors such as a firm's behavior, intention and vision (Chua et al. 1999). From this perspective, family involvement is only a necessary condition -such family involvement must be "directed toward behaviors that produce certain distinctiveness before it can be considered a family firm" (Chrisman et al. 2005, 557). Accounting studies such as Stockmans, Lybaert and

\footnotetext{
${ }^{3}$ Studies such as Chua et al. (1999), Astrachan et al. (2002), Sharma (2004) and more recently Chua et al. (2012) and Diéguez-Soto et al. (2015) provide literature reviews on the definition of family business.
} 
Voodeckers (2013) follow this approach and define family firms taking into account the involvement of the family (ownership, management and control) as well as the CEO's perception about the firm being a family firm.

In both the components-of-involvement and the essence approaches, researchers typically use dichotomous variables based on the relevant criteria to distinguish family and non-family firms. Astrachan et al. $(2002,46)$ argues, however, that "artificially dichotomizing family vs. nonfamily firms when no such clear-cut dichotomy exists creates more problems than it attempts to solve" and that "there are discrete and particular qualities or characteristics of a business that are more appropriately measured on a continuous rather than dichotomous scale". Accordingly, they propose a more sophisticated measure of the extent and manner of family involvement in and influence on the firm using a continuous scale, which combines information about three relevant dimensions: power, experience and culture (the F-PEC index of family influence; see also Klein, Astrachan, and Smyrnios 2005). In our review, the only study that have adopted (indirectly) the framework proposed by Astrachan et al. (2002) is Dekker et al. (2015). They follow Astrachan et al.'s (2002) work to develop a survey able to assess the amount of nonfamily involvement within the management team.

The challenge of defining family firms is far from being resolved. Furthermore, assuming that researchers agree on a definition of family firm, its operationalization is always problematic. As highlighted by Evert et al. $(2016,28)$, the real difficulty lies in measuring the intangible attributes associated with any given definition of family firm. In the last section, we briefly discuss some opportunities for future research arising from this empirical challenge. 


\section{Financial Accounting and Reporting in Family Firms}

Most prior studies on accounting and family firms are quantitative studies focused on the financial reporting characteristics of family firms. With few exceptions, they adopt the agency framework to investigate accounting choices (e.g., EM and voluntary disclosures) that impact on financial reporting quality of family firms compared to non-family firms. The dominance of the agency theory is not surprising, since mainstream accounting research is based extensively on the agency framework.

Agency theory (Jensen and Meckling 1976) focuses on the relationship between managers and owners and to what extent this relationship influences on the agency costs -i.e., the costs of all activities designed to align the interests of managers (agents) and owners (principals). Given the close relationship between the family and the managers, these costs are expected to be lower in the case of family firms. They are, therefore, less likely to be affected by the so-called "Type I" agency conflicts related to the separation of ownership and management. However, we may expect more prominent agency costs related to the conflict between the family owners and other owners -the so-called "Type II" agency problem. Specifically, there are potential agency costs to minority shareholders in those situations where the family acts as a dominant shareholder as the controlling family may try to maximize its private benefits at the expense of minority shareholders (Villalonga and Amit 2006; Bhaumik and Gregoriou 2010). Furthermore, agency costs can also arise from lender-owner conflicts of interests (Chrisman, Chua, and Litz 2004) ${ }^{4}$. Research based on the agency theory has put forward two opposing views about the association between family control and the quality of accounting decisions. On the one hand, the interest

\footnotetext{
${ }^{4}$ For an analysis of agency relations and agency costs in family firms, see Schulze et al. (2001) and Chrisman et al. (2004) respectively.
} 
of the controlling family in the long-term survival of the firm as well as the privileged position of the family to supervise and monitor managers may lead to better accounting decisions, which in turn will lead to higher reporting quality (the alignment hypothesis). On the other hand, the controlling family may manipulate the information about the actual performance to expropriate the wealth of other (minority) shareholders. From this perspective, the presence of a controlling family is expected to be associated to accounting decisions of lower quality (the entrenchment hypothesis).

\subsection{Financial Reporting Quality}

Financial reporting quality refers to the usefulness of the information contained in the annual reports. Earnings management (EM) and voluntary disclosures are considered two key tools firms can use to influence the quality of financial reporting (Gomez-Mejia et al. 2014). Given their relevance in prior literature, we explore them in the following sections.

The results about the association between family ownership and financial reporting quality are mixed. Studies such as Wang (2006), Tong (2007) and Cascino et al. (2010) find that family firms provide accounting information of higher quality than non-family firms do. Other studies, however, provide evidence of a negative relationship between family control and quality of financial reporting (e.g., Prencipe, Markarian, and Pozza 2008; Yang 2010).

Using conservatism as a proxy for financial reporting quality, Chen et al. (2014) provide evidence of a positive association between conservatism and family ownership. They argue that family owners have both the incentives and the ability to implement more conservative financial reporting practices to reduce the risk of legal liability and to mitigate the potential agency conflicts with other shareholders (alignment hypothesis). Their results support such prediction: conservatism increases with family ownership if and only if the founder is not acting as the 
CEO. Such association, however, is not significant when the founder is serving as a CEO in a family firm. Thus, the quality of financial reporting may vary depending on the governance characteristics of the family firm. Srinidhi, He, and Firth (2014) differentiate between strongly and weakly governed family firms and find that strongly governed family firms exhibit higher earnings quality than other family firms. This result suggests that strong board governance can effectively mitigate the adverse consequences of Type II agency problems.

Recent studies use material weaknesses in internal controls ${ }^{5}$ as a proxy for financial reporting quality, with no conclusive results. Weiss (2014), examining a sample of Israeli companies, find that family firms report less material weaknesses in internal controls suggesting higher financial reporting quality. However, in the presence of material weaknesses in internal controls, family firms produce lower earnings quality than non-family firms. Interestingly, the market reaction is more negative in the case of family companies. Bardhan, Lin, and Wu (2015), using a sample of US companies, finds opposite results: family firms exhibit more material weaknesses in their internal control over financial reporting than non-family firms. They also find that the greater likelihood of material weaknesses is driven by family firms with dual-class shares, in line with the entrenchment hypothesis.

Ma, Ma, and Tian (2017) provide evidence about the consequences of corporate opacity of family firms. Using a sample of 705 Chinese firms, they find that corporate opacity acts as a moderator in companies with controlling families. The results show that family control is associated with a lower cost of debt on average but there is a negative impact in firms with

\footnotetext{
${ }^{5}$ In this context, a material weakness in internal control is "a deficiency, or a combination of deficiencies, in internal control over financial reporting, such that there is a reasonable possibility that a material misstatement of the company's annual or interim financial statements will not be prevented or detected on a timely basis" (Auditing Standard No. 5 2007).
} 
relatively lower corporate performance, particularly when investors perceive a high risk of families' moral hazard of expropriation.

All papers above are based on the agency framework. Gomez-Mejia et al. (2014), in a conceptual paper, develop an integrated framework to financial reporting decisions in family firms based on the Socioemotional Wealth (SEW) approach. The SEW approach argues that family firms consider the nonfinancial aspects of the firm (socioemotional wealth) that meet the affective needs of the family, such as the perpetuation of the dynasty. Using a cost-benefit analysis of accounting choices, the paper develops different propositions regarding the probability of a firm to engage in practices that influence the financial reporting quality (EM and voluntary disclosures) depending on two dimensions of SEW: "family control and influence" and "family identification". The empirical validation of this model is an opportunity for future research.

\subsection{Earnings Management}

Earnings management (EM) occurs when managers use the discretion within the accounting standards to alter the financial reports either to mislead shareholders about the economic performance of the firm or to influence contractual outcomes whose result depends on the reported accounting numbers (Healy and Wahlen 1999, 368). Accountants distinguish between real EM, which refers to decisions that affect the timing and scale of operating, investing and financing activities in the accounting period and accruals EM, which relate to pure accounting decisions. EM has been extensively examined in the accounting literature (for a review, see Dechow, Ge, and Schrand 2010) and so on the research at the intersection between accounting and family firms -see Bhaumik and Gregoriou (2010) and Sousa-Paiva et al. (2016). 
A number of studies has explored to what extent family firms are more or less likely to use EM techniques to manipulate earnings. Adopting an agency framework, Ali, Chen, and Radhakrishnan (2007) and Jiraporn and Dadalt (2009) use US data to show that family firms, when compared to non-family businesses, are less likely to manage earnings. This result is supported by studies examining data from other settings. Prencipe et al. (2011) analyze a sample of Italian family and non-family firms and find that the probability of income smoothing practices is lower for family firms. Prencipe et al. (2008) find that family firms are less sensitive to income-smoothing motivations than their non-family firms' counterparts, even though they have similar motivations to manage earnings to avoid violations of debt covenants. Research has also showed that the role of the board of directors on monitoring EM is affected by the presence of family members on the board (Prencipe and Bar-Yosef 2011) and by the proportion of outside directors and CEO duality when the firm faces significant agency problems between controlling and noncontrolling shareholders (Stockmans et al. 2013).

Some studies have compared EM in family firms across countries, with no conclusive results. Martínez-Ferrero, Rodríguez-Ariza, and Bermejo-Sánchez (2015) examine a sample of listed companies from 20 countries and find that family ownership exerts a controlling and monitoring role on managerial decisions: the higher the degree of family ownership, the lower the risk of a conflict of interest between owners and agents, and of the expropriation risk of managers acting for their own benefit. These results are in line with the alignment hypothesis. Cruz et al. (2015) compare the behavior of European family and non-family firms and find that family firms are less likely to opportunistically smooth earnings as capital market conditions deteriorate.

Studies using international samples have shown that the institutional setting matters. Gopalan and Jayaraman's (2012) results suggest that a country's institutional environment determines 
whether insider controlled firms, including family firms, are associated with more or less EM than non-insider controlled firms. Specifically, insider controlled firms that operate in low investor protection countries are associated with more EM than their non-insider controlled counterparts. Mengoli and Pazzaglia (2017), using a sample of family and nonfamily firms in 12 European countries, find that the institutional development of a country has a moderating effect on earnings quality. Specifically, well-developed formal institutions have a more beneficial effect on the earnings quality of non-family firms than that of family firms. Informal institutions such as families, however, are beneficial and have a particularly positive influence on firm's behavior in countries with no formal institutions. Within the agency framework, JaraBertin and López-Iturriaga (2014) use a sample of 3559 listed firms from Canada, France, Italy, Spain, the UK and the US to examine how the distribution of power among shareholders affects EM in family firms. They find that the more challenge to the control of dominant shareholders, the less EM in family firms. The legal-institutional environment affects this result: in civil law countries where the rights of shareholders are less protected, the contest of control becomes more relevant.

The differences in the institutional environment may explain why studies based on Asian samples (e.g., data from Taiwan and China) find that EM increases with the level of insider ownership in family controlled-companies (e.g., Yang 2010; Ding, Qu, and Zhuang 2011; Chi et al. 2015) ${ }^{6}$ in contrast with the results of studies examining US or European samples (Ali et

\footnotetext{
${ }^{6}$ Consistent with the evidence from other Asian countries, Razzaque, Ali, and Mather (2016) show that Bangladeshi family firms engage in more real EM than non-family firms. However, they find a curvilinear relationship between family ownership and real EM: it increases with the increase in family ownership and after reaching a certain ownership threshold, it tends to decline.
} 
al. 2007; Prencipe et al. 2011) ${ }^{7}$. As suggested by Sousa-Paiva et al. (2016), this may indicate that the presence and influence of Type II agency problem in Asian family firms is more severe than in Western countries such as US or Italy.

In contrast to the studies discussed above, which are based on the agency theory, Achleitner et al. (2014) adopt the SEW approach to examine EM in a sample of German firms. According to the SEW approach, the motivation of EM depends on whether or not the family owners give priority to the "family control and influence dimension" over the "family identity" dimension (Gomez-Mejia et al. 2014). In line with the predictions of the SEW theory, Achleitner et al. (2014) find that family firms are less likely to engage in real EM and in earnings-decreasing EM because of their interest to preserve the wealth of the company for future generations.

Following the SEW approach, some studies have investigated to what extent EM changes depending on the type of family firm (e.g., Stockmans, Lyabert, and Voordeckers 2010; Pazzaglia, Mengoli, and Sapienza 2013; Martin et al. 2016). Stockmans et al. (2010) find that when the financial performance is poor, the interest of the family to preserve the SEW explains the decision to manipulate earnings upwards. Accordingly, in case of low performance, first generation and founder-led family firms engage in more in upward EM than other type of family firms. Pazzaglia et al. (2013) find that firms that have been acquired by the current family owners as a result of a market transaction show higher EM than firms created or inherited by the family. Consistent with prior studies, Martin et al. (2016) find that founder family firms are less likely than non-founder family firms to use EM, suggesting that family owners are loss averse with respect to the SEW of the family.

\footnotetext{
${ }^{7}$ In the case of Portugal, Simões-Vieira (2016) finds no significant differences in the incentive to manage earnings between family and non-family firms in a sample of public firms the period 1999-2011.
} 


\subsection{Voluntary Disclosures}

Voluntary disclosures refer to the managerial decision to provide information about the company beyond the requirements established by regulators. Previous studies have paid attention to the quality and quantity of voluntary disclosures of family firms as compared to non-family firms. The results suggest that family firms are more likely to warn for bad news (e.g., Ali et al. 2007; Chen, Chen, and Cheng 2008), to make fewer disclosures about corporate governance (Ali et al. 2007), and to provide fewer earnings forecasts and conference calls (Chen et al. 2008). Prior studies have also examined the impact of corporate governance mechanisms on financial disclosures (Chen and Jaggi 2000).

We identify two studies on voluntary disclosures. Golden and Kohlbeck (2017) explore the voluntary disclosure practices of family firms and test whether there is an association between the disclosure of earnings forecasts by the management and the compensation of CEOs in the context of family firms. Using firms of the S\&P 1500, they find that family firms are less likely than non-family firms to provide earnings forecasts on a voluntary basis when their CEO's wealth is higher. These results holds when a member of the family is acting as CEO or is a member of the board of directors. Muttakin, Khan, and Belal (2015) focus on non-financial disclosures. Using a sample of 135 Bangladeshi companies, they look at disclosures of intellectual capital to see whether there is an association between family ownership and nonfinancial disclosures. They find that there is a non-linear relationship between family ownership and the disclosure of intellectual capital, which are less likely when members of the family occupy the CEO and the chair's position. 


\subsection{Other Accounting Decisions}

The first accounting studies providing indirect evidence on accounting decisions of family firms focused on the association between managerial ownership (typically high in a founder-family controlled firm) and accounting choices such as depreciation methods (Dhaliwal, Salamon, and Smith 1982) and inventory accounting methods (Niehaus 1989). Recently, Greco, Ferramosca, and Allegrini (2015) examine the decision to write-off long-lived assets using a sample of Italian companies. They find that the write-offs of long-lived assets of family firms are coherent with the firm performance, thereby rejecting the entrenchment hypothesis. However, nonfamily firms tend to use write-offs to manipulate earnings. This evidence is consistent with family concerns about the reputation damage associated with a loss of a firm's asset value, a characteristic that it is not detected in non-family firms.

With the process of harmonization of accounting standards and the adoption of International Financial Reporting Standards (IFRS) in many countries, the interest in the variation of accounting choices across firms in different countries has decreased (Salvato and Moores 2010). However, the adoption of IFRS has revived the interest in firms' accounting choices and firms' reaction to changes in accounting regulation. For example, Chen et al. (2016) explore to what extent a change in accounting standards (adoption of IFRS) influences on family and nonfamily firms in their attempts to get debt financing from foreign banks. After examining 6950 firms from 80 countries, they find that family firms tend not to change from local Generally Accepted Accounting Principles (GAAP) to IFRS on a voluntary basis and this has a negative impact on their ability to access to debt capital. Nagar and Sen (2016) compare US and Indian companies to examine the quality of cash flow reporting after a change in the regulation of cash flow reporting. They also examine to what extent there are variations between family and non- 
family firms in the two countries. They find evidence of manipulation of cash flows in India and the US although such manipulation is different for family and non-family firms in India.

\section{Management Accounting and Management Control in Family Firms}

Research on management accounting and control has a long tradition in accounting (e.g., Chenhall 2003). By management accounting practices we refer to tools such as product costing, budgets for planning and control, standard costing variance analysis among others. Strategic management accounting is also a management accounting tool, which includes techniques such as the Balance Scorecard or target costing (Lucas, Prowle, and Lowth 2013). In spite of its interest, this area of research is significantly less explored in the context of family firms than that of financial accounting -see Senftlechner and Hiebl (2015) and Helsen et al. (2017) for a comprehensive review of the literature.

One of the challenges in management accounting research is the access to data and most studies rely on information collected from surveys or interviews. Prior studies on management accounting in family firms have focused on the following three areas: (i) drivers for the adoption of management accounting and control practices in family firms; (ii) type of management control practices adopted by family firms, and (iii) the role of management accounting in family firms. We explore them in the following sections.

\subsection{Drivers of Adoption of Management Accounting and Control Systems}

Prior studies have examined what drives the adoption of management accounting and control systems in family firms. Business size and growth are consistently considered as key drivers of adoption of managerial accounting practices (Giovannoni, Maraghini, and Riccaboni 2011; Speckbacher and Wentgest 2012). Some studies have examined the role of trust, although the 
results are not conclusive. While some studies find that family's trust in the management of the company may reduce the need for management accounting (Moilanen 2008; Tsamenyi, Noormansyah, and Uddin 2008; Stergiou, Ashraf, and Uddin 2013), others (e.g., Giovannoni et al. 2011) find that trust may be irrelevant in a scenario where the company is growing and facing increasing complexity. In those cases, there is a need for more formal control systems irrespective of the level of trust of the family in the management.

Other papers have explored to what extent the family orientation of the business may influence on the adoption of management accounting practices and control systems. By and large, results show that higher levels of family orientation have a negative effect on the adoption of management accounting and control systems and on their relevance for the organization (Leenders and Waarts 2003; Tsamenyi et al. 2008; Uddin 2009). Results also show that the family's involvement in the management is negatively associated with the use of performance measures in strategic target setting and incentive practices (Speckbacher and Wentges 2012). Human agency plays a critical role in the process of adoption of management control practices and on management accounting change (Hiebl, Duller, and Feldbauer-Durstmüller 2012; Stergiou et al. 2013; Baños-Sánchez Matamoros, Araujo-Pinzón, and Alvarez-Dardet Espejo 2014; Efferin and Hartono 2015). Baños-Sánchez Matamoros et al. (2014), in a study on management accounting change in a Spanish family firm, find that the drivers of accounting change are strongly influenced by actors' interests and by their perception and interpretation of institutional contradictions and external events. Both the type of change and the process are shaped by the normative influences to which the actors are subject to. Efferin and Hartono (2015), examining an Indonesian firm, find that there is a close relationship between the leadership style and the management control system adopted. They also find that the owner and 
her/his inner circle play crucial roles in producing and reproducing the legitimate management control system based on the extended family concept.

As far as the role of management accountants is concerned, Giovannoni et al. (2011) and Hiebl et al. (2012) find that management accountants see themselves as drivers of change. Cesaroni and Sentuti (2017), however, find somehow a contradictory result. Using a sample of 1756 Italian certified accountants, they find that accountants are mostly concerned with technical issues showing relatively low interest in the interaction and communication with family members. This may cause a discrepancy between the accountant's professional practice and the expectations of the family about her/his role in the company.

\subsection{Type of Management Accounting and Control Systems}

The evidence available suggests that family firms' approach to managerial accounting differs significantly from the experience of non-family firms (e.g., Durendez, Madrid-Guijarro, and García-Pérez-de-Lema 2011; Samuelsson et al. 2016). Specifically, research shows that small and medium family business consider management accounting and control systems as less relevant than similar non-family business (Durendez et al. 2011) and that they tend to use less sophisticated tools (e.g., Neubauer et al. 2012; Samuelsson et al. 2016). Samuelsson et al. (2016), after examining data collected from 156 Swedish manufacturing firms, find that these firms use less formal planning than non-family firms. They also find a strong positive association between the entrepreneurial orientation and the use of formal planning mechanisms. Differences between family and non-family business tend to disappear in the case of family business managed by non-family members, which in turn is related to the size and complexity of the company as suggested above (e.g., Giovannoni et al. 2011; Speckbacher and Wentges 2012). As far as effectiveness of management control systems is concerned, Speckbacher and 
Wentges (2012) find no evidence between family and non-family businesses in a sample of 304 Austrian and German companies.

\subsection{Importance of Management Accounting and Control Systems}

There are mixed results regarding the importance of management accounting processes, such as strategic planning or informal management control systems, for family firm performance. While some studies find that they have a positive influence (e.g., Songini and Ghan 2015), others (Dekker et al. 2015) find no association between formal financial controls and firm performance. Songini and Gnan (2015) use a sample of 146 Italian companies and find that agency cost control systems in family business affect firm performance. Dekker et al. (2015) examine the formal controls of a sample of Belgian family business and find no evidence of an association between formal financial controls and firm performance. However, they do find a positive effect of HRM control systems on financial performance. The lack of consistency in the results is not surprising, given that comparability of studies in management accounting is difficult due to the type of data, the variation in practices across jurisdictions and firms and the different approaches used by researchers.

Studies examining the role of managerial accounting in family firms have also shown that management accounting practices can influence significantly the transfer of knowledge across generations as well as between the management team and the family (Giovannoni et al. 2011). However, such influence depends on the size of the company, in line with the results described above. In the case of medium-size firms, in contrast to large firms, the presence of a controlling family has a negative influence on the use and institutionalization of management accounting practices (Hiebl, Feldbauer-Durstmüller, and Duller 2013). 


\section{Auditing in Family Firms}

The purpose of an audit of financial statements is to express an opinion on the fairness with which they present, in all material respects, the financial position, results of operations and the cash flow statement of a company in conformity with the GAAP. The distinct characteristics of family firms compared to non-family firms are expected to influence on the demand for auditing, the audit process, and the audit outcomes (audit quality and audit fees) ${ }^{8}$. There are few studies on the intersection of family firms and audit research (see Trotman and Trotman 2010). These studies, adopting an agency framework, have focused on the demand of auditing, the demand for audit quality (auditor choice) and audit fees.

\subsection{Demand for Voluntary Audits}

What explains the demand for external audits of family firms? This has been the research question of some studies (e.g., Carey, Simnett, and Tanewski 2000; Corten, Steijvers, and Lybaert 2015). Given the lower Type I agency costs, family firms are expected to demand less voluntary external audits. Carey et al. (2000) argue that family firms consider internal and external audit as substitutes. Using a sample of Australian companies, they show that family firms demand more internal audits than voluntary external audits and that nonfamily involvement has a positive correlation with the demand of voluntary audits. They also show that the demand of voluntary external audits increases with agency costs and leverage. Corten et al. (2015), examining a sample of 482 US companies, argue that the level of shareholderdebtholder agency costs seems to be a key driver for the demand of voluntary audits by family

\footnotetext{
${ }^{8}$ For a review of archival auditing research, see DeFond and Zhang 2014.
} 
firms. With low presence of such agency costs, other work done by auditors such as reviews and compilations seem to be sufficient and more cost-effective for family firms.

Finally, it is worth mentioning the study of Collin et al. (2017). Using data collected from 309 Swedish auditors, they find that in family firms, auditors perform primarily a monitoring role but they also act as consiglieres by performing the advisory and mediating functions and, to a smaller degree, the conveying function. The results suggest that for family firms, the demand for voluntary audits may be explained by factors not necessarily related to assurance of the financial statements.

\subsection{The Demand for Audit Quality and Choice of Auditor}

A recurrent research question in auditing is what explains the demand of "high quality audits". Many studies use the type of auditor as a proxy for audit quality under the assumption that "big audit firms $9 "$ provide audit services of higher quality as compared to other audit firms. Studies on family firms have focused on two issues: a) whether family firms demand more or less audit quality than non-family firms, and b) what explains the decision to hire a "big auditor". Overall, the evidence suggests that family firms demand less audit quality (Niskanen, Karjalainen, and Niskanen, 2010; Hope, Langli, and Thomas 2012; Ho and Kang 2013).

Niskanen et al. (2010) and Ho and Kang (2013) find that increases in family ownership decreases the likelihood of hiring top-tier auditors. Similarly, Hope et al. (2012) show that for settings where the $\mathrm{CEO}$ is related to the major shareholders there is no greater demand for Big auditors. These results are in line with the alignment hypothesis. In a recent article, Corten, Steijvers, and Lybaert (2017) using a sample of 125 Belgian firms show that high quality

\footnotetext{
${ }^{9}$ The "Big 4" today: Deloitte, E\&Y, KPMG and PricewaterhouseCoopers.
} 
auditors are hired to mitigate intra-family agency conflicts. Such demand decreases when the family firm can reduce the agency costs internally.

Research has also used the decision of hiring an industry-specialist auditor as a proxy for high audit quality. Kang (2014) find that family firms are more likely to appoint an industryspecialist than non-family firms, and such tendency is even stronger in the case of family firms where the CEO belongs to the family or there are dual-class shares. In contrast to the findings above, these results are in line with the entrenchment argument. In a similar vein, Srinidhi et al. (2014) use as a proxy for audit quality being a specialist auditor. They find that for family firms with strong corporate governance mechanisms there is a higher demand of high quality audits.

Khalil and Mazboudi (2016) explore the resignation and appointment of a new auditor in family and non-family firms using a sample of US firms. They find that, after the resignation of the incumbent auditor, Big 4 auditors perceive family firms as being less risky than non-family firms and that Big 4 are more likely to accept such engagements.

\subsection{Audit Fees}

Overall, research shows that family firms demand lower audit effort and, hence, pay lower audit fees (Ho and Kang 2013; Ghosh and Tang 2015; Barroso, Ali, and Lesage 2016). Ho and Kang (2013) find that family firms incur in lower audit fees than non-family firms due to the lower demand for external auditing services and the auditors' lower perception of risk in the case of family firms. The fees' difference is stronger in the case of family firms where family owners actively monitor their firms. Ghosh and Tang (2015) report similar findings: auditors charge less audit fees because the superior reporting quality lowers audit risk and reduces auditors' costs. Barroso et al. (2016), in a study examining the moderating role of the corporate 
governance model on the association between blockholders' ownership and audit fees, investigate the effects of family ownership as an additional analysis with results consistent with those reported by Ho and Kang (2013) and Ghosh and Tang (2015). Khalil and Mazboudi (2016) examine the changes in audit fees after the resignation of an auditor and find that the change is smaller in the case of family firms as compared to non-family firms.

However, Hope et al. (2012), examining a sample of Norwegian companies, find opposite results about the family involvement in the management and audit fees. Specifically, they find that when the CEO is a member of the largest owning family, audit fees increase, which is consistent with the argument that when a family relationship exists, shareholders are less likely to act as independent monitors of the CEO. As a result, the probability of misappropriation by the CEO or extraction of private benefits by controlling owners increases.

\section{Accounting History}

Accounting history is an expanding and maturing sub-discipline of accounting (Walker 2009). It matters because it allows us to understand "accounting's past and present and it provides insights into the future of accounting" (Carnegie and Napier 2012). Although the research interest of accounting historians on family firms is limited if compared to research done by economic and business historians (Fernández-Pérez and Puig 2013), some of the contributions bring relevant insights about the role of accounting in family firms (see Table 3$)^{10}$. These studies focus primarily on accounting change in the context of family firms, accounting as an explanatory factor of success/failure, and family firms and the development of auditing.

\footnotetext{
${ }^{10}$ As suggested by Mathias (1993) there is a potential synergy in the disciplines of accounting history and business history. While business historians can contribute by their knowledge and understanding of the context within which accounting evolves, accounting historians' knowledge can help to interpret empirical, quantitative information as well as reduce the risks of misrepresentation.
} 


\subsection{Studies on Accounting Change}

We identify two studies whose aim is to provide insights about the drivers of accounting change from a historical perspective. Using relational contract theory, Álvarez-Dardet and Capelo (2003) examine a Spanish company (Almacenes Agüera) during the period 1740-1835 and demonstrate that accounting change was driven by internal factors (separation between ownership and management and changes of the contractual relationships within the firm) as well as by external factors (general level of economic activity and government legislation). Baños-Sánchez Matamoros et al. (2014) adopt an institutional entrepreneurship approach to examine the development of Medina Garvey, a Spanish family firm, for the period 1904-1969. The case illustrates how the agent-owner "rationally" promoted the transformation of management practices, acting as an "institutional entrepreneur". The study also shows how both structures and human agency played a "mutually constitutive role in fostering and shaping management accounting change” (Baños-Sánchez Matamoros et al. 2014, 257).

From a financial reporting perspective, Camfferman and Zeff (2003) investigate the origins of the modern and innovative consolidated financial reporting practices of Unilever in the 1940s. Before the World War II, Unilever and its subsidiaries were criticized for their uninformative reporting and the company was described as a "retarding factor in the modernization of financial reporting" (Camfferman and Zeff 2003, 197). However, the company and its top executives were already considering consolidated financial reporting and other innovative financial reporting practices during the 1930s and the 1940s. The paper shows that these changes coincided with the transformation of the company from a family-dominated firm into a professionally managed organization. Besides rehabilitating the image of Unilever in financial 
reporting history, the paper also demonstrates that the company and some of its top executives influenced on the financial reporting reform in Britain during the 1940s.

\subsection{Role of Accounting in the Success and Failure of Family Firms}

Some studies provide insights about the key role played by financial and accounting controls in the success and failure of family firms (Kininmonth and McKinstry 2007; Vent and Milne 2000; McWatters 2002; Robb, Shanahan, and Lord 2006). Kininmonth and McKinstry (2007) study the case of J\&P Coats Ltd, one of the Britain's largest multinational company from the period 1890 to 1960 , and show how the consolidation accounting, the control and funding of subsidiaries, the private and confidential ledgers kept by the company and the management accounting practices contributed to organizational control. The success of the company was partly due to its tight accounting systems and controls, the authors argue. Vent and Milne (2000) examine the accounting practices of St. Joseph Lead Company. Compared to other companies in the mining industry during the second half of the nineteenth century, the company used a crude double-entry bookkeeping system and did not use detailed cost accounting records. These practices were far behind the practices of the contemporary mining firms.

McWatters (2002) adopts an organizational-economics framework to examine organizational failure. The paper analyzes the case of the Kingston Shipping Company Ltd and the role of the accounting system in the development of the company at the early-twentieth century. The accounting system reported and accounted for the operations and produced standardized information although there were important shortcomings related the accounting treatment of investments and financing costs. By obscuring certain information, the accounting system created an "accounting reality" which was quite different to the actual results of the company. That is, "the lack of profitability would have been much more apparent had the accounting 
reality been a different one" (McWatters 2002, 83). While the examination of accounting records may provide insights into actions of individual firms, McWatters (2002) argues that the role of accounting records in business history research must be underscored. Accounting records, he argues, are the result of choices and decisions at a given point and setting (McWatters 2002, 56).

Robb et al. (2006) examine the transformation of Adams Bruce Ltd (a bakery in New Zealand), from family ownership to public ownership and professional management. Using both written and oral evidence, the paper shows three different narratives grounded on agency theory. The family narrative describes a company with more than 50 years with sustained growth. There was an accountant who was there for 40 years and the family felt that his skills and the accounting systems, focused on cost control through variance analysis, enabled the firm to achieve operational efficiency. The professionally managed firm narrative starts when an outsider was appointed as CEO. Conflicts were frequent between the new appointed team and the "old school". Importantly, the use of informal communication networks common in the previous period declined, with negative consequences of the company. Costs increased significantly leading to a less efficient company when compared to the previous situation. Part of the problem was the lack of planning for the transition from a family controlled company to a non-family controlled company. Finally, the narrative of the takeover period evidences that control can be quickly changed in the case of listed companies. This company is an example supporting the claim that family firms can be in some instances more efficient than non-family controlled firms. 


\subsection{The Origins of Auditing and Family Firms}

Some accounting historians have paid attention to the link between the development of auditing as a practice and family firms (e.g., Popp 2000; Matthews 2006; Fourness-Datin 2014). Popp (2000) investigates the role of auditors and auditors' reports in the context of "personal capitalism" (Lloyd-Jones and Lewis 1994). The paper focuses on Mintons Ltd, a firm owned by a single family with no external investors, where the family is involved in the day-to-day management and the family name is considered as a guarantee of quality in the market. It provides some insights about Mintons' motivations to hire professional external auditors. Like in other cases at that time, auditors acted more as advisors than as independent reviewers. The audit reports show how auditors positioned themselves as providers of strategic business advice beyond accounting issues, although their recommendations were sometimes disregarded. Minton's employment of “elite" auditors (Deloitte, Dever, Griffith and Co.) could be seen as a signaling strategy, "conveying images of status and professionalism commensurate with the reputation of this long-established firm" (Popp 2000, 363).

Matthews (2006) collected data from interviews to retired and practicing chartered accountants and from postal questionnaires to investigate the changes in auditing techniques over time. The study shows that auditing techniques before 1960s fitted the needs of family firms, the typical audit clients at the time. In line with Popp (2000), auditors were perceived as advisors willing to help owners to prepare the accounting of the business instead of an independent third party. However, the changes in family control of companies over time had a significant impact on audit procedures. Specifically, he shows that the decline of family control and professionalization of management explains changes in auditing procedures in the 1960s. 
Finally, Fourness-Datin (2014) examines the impact of the Company Act of July 1867 requiring statutory audit for French limited companies. To illustrate the actual practice of statutory auditing, the article examines two major industrial firms: Pont-à-Mousson, a family business example of what is called "personal capitalism", and Saint-Gobain, a very old traditional company which could be considered as a managerial firm. In spite of the differences in the governance and capital structure of the two companies, in both cases the auditor was considered above all "the right-hand man" of the board of directors, playing the role of advisers to the board, and working very closely with directors. This evidence is consistent with the findings of Popp (2000) and Matthews (2006).

\section{Advancing Accounting Research in Family Firms}

The empirical and theoretical challenges faced by researchers interested in family firms are quite similar, irrespective of the field of knowledge. Accounting researchers could benefit from the advancement of knowledge in other disciplines such as general management, business or economics to further develop an understanding of the role of accounting in family firms. Next, we discuss some theoretical and empirical challenges and suggest some avenues for future research

\subsection{Theoretical Challenges - Opportunities}

As noted above, agency theory is by far the most prevalent theoretical framework adopted in prior studies on family firms. Interestingly, these studies have help to expand the theoretical boundaries of the agency theory by including agency problems and conflicts originally overlooked (Madison et al. 2016). Agency theory is also the dominant theoretical framework in accounting research in family firms. With few exceptions (e.g., Achleitner et al. 2014; Baños- 
Sánchez et al. 2014), all papers identified in this review follow the insights of the agency theory. Future research adopting the agency framework could explore in depth the association between complex ownership structures, the role of the family and accounting transparency. One example is the case of pyramidal ownership structures, very common but obscure control mechanisms which make it difficult to identify who is the most influential shareholder of the firm (Levy 2009). For example, the controlling family may use pyramidal structures to manipulate earnings by means of related party transactions (Bhaumik and Gregoriou 2010). Further evidence on this area is needed. Future research could also explore the role of auditors in the context of complex ownership structures, where the opportunities and incentives of owners-managers may influence auditors' fraud risk assessments.

In spite of the dominance of mainstream agency theory, some researchers argue that it "oversimplifies the complexity of exchange that occur among the family firm's decision agents" (Schulze, Lubatkin, and Dino 2002, 247). In a family firm, the agency relationships are characterized by the past and ongoing parent-child relationships of the family and, therefore, by altruism (Schulze, Lubatkin, and Dino 2003). While the classical agency view suggests that the ownership should align the interest among family agents, altruism, defined as "a moral value that motivates individuals to undertake actions that benefit others without any expectation of external reward" (Schulze et al. 2002, 252) may generate other agency problems. Specifically, it exposes family firms to adverse selection -the agency threat associated with the lack of ability (Schulze et al. 2003, 477). Schulze et al. (2003) use the insights of household economics and altruism literature to explain how altruism influences agency relationships in the case of family firms. An understanding of the dynamics of family firms taking into account the altruism component may help to bring light on issues related to accounting change (e.g., Giovannoni et 
al. 2011). Specifically, altruism may help to explain the role of different management and control practices over the life of the firm, given the different impact that altruism may have on the different phases of entrepreneurship. Future research could also explore the role of altruism in the demand of formal mechanisms of control, including external mechanisms of governance such as auditing.

Stewardship theory is another prominent perspective in prior research on family firms (Davis, Schoorman, and Donaldson 1997; Madison et al. 2016). Instead of assuming the economic model of the individual as in the agency theory, the central assumption is a humanistic model where managers act as responsible stewards and whose behaviors are aligned with the objectives of principals (Madison et al. 2016). In accounting, few papers have adopted the stewardship theory, always together with the agency theory (e.g., Prencipe et al. 2008; Speckbacher and Wentges 2012). Madison et al. (2016) review the literature on family firms through the lens of agency and stewardship theories and identify some future areas of research to push the theoretical boundaries of these two frameworks and offer new insights into the family firm that could be relevant for accounting researchers examining financial reporting quality.

Recently, several papers on accounting have adopted the SEW approach, which is an extension of behavioral agency theory applied to the field of family firms (Wiseman and Gomez-Mejia 1998; Gomez-Mejia, Welbourne, and Wiseman 2000; Berrone, Cruz and Gomez-Mejia 2012). The behavioral agency theory considers that firms make choices depending on the reference point of the principals of the firm. These principals will make decisions so that they can preserve accumulated endowment in the firm. In the case of family firms, the emphasis on preserving the SEW becomes critical. Importantly, the family may be willing to make decisions driven by 
a non-economic logic in order to preserve the endowment. Accounting studies assuming the SEW approach (Achleitner et al. 2014; Gomez-Mejia et al. 2014; Cruz et al. 2015; Martin et al. 2016) provide support for some of its insights of the SEW approach. Much more work in required on this area -e.g., to test empirically the propositions developed by Gomez-Mejia et al. (2014) on SEW and earnings quality.

The RBV approach assumes that firms are able to sustain their competitive advantage when they have valuable and rare resources that cannot be easily imitated or substituted by their competitors (Barney 1991). In the case of family firms, the RBV focuses on identifying the strategic resources derived from the interaction between the family and the business systems, taking into consideration both economic and non-economic factors (Le Breton-Miller, Miller, and Bares 2015). Among the family-unique resources and capabilities, prior work places emphasis on factors such as human capital, social capital and governance structure and how they give advantages or disadvantages to family firms (Sirmon and Hitt 2003). Habbershon and Williams (1999) apply the theoretical framework provided by the RBV to family firms and define the concept of familiness. Familiness refers to "the unique bundle of resources a particular firm has because of the systems interaction between the family, its individual members, and the business" (Habbershon and Williams 1999, 11). It is argued that the creation of distinctive and enduring familiness may be a driving force behind the vision and goals of family firms (for a literature review of the concept familiness see Frank et al. 2010; also Pearson, Carr and Shaw 2008). Accounting research could consider insights from this framework and adopt the notion of familiness to investigate how and to what extent the relationships among family members and their relationships with the business influence on the implementation of management control systems and their success or failure. Furthermore, it has 
been argued that the effect of national culture may be stronger in family firms compared to nonfamily firms due to the influence of the national culture on the family organization and structure (Vallejo 2011; Fletcher, Melin, and Gimeno 2012). Comparative studies examining the implementation of control systems in family firms located in different institutional environments may bring some interesting insights about the influence of culture on family firms compared to non-family firms.

Building on the work of Habbershon and Williams (1999), social capital theory has been adopted as a framework to examine some dimensions of familiness that the RBV does not take into account (Pearson et al. 2008; Frank et al. 2010). Arregle et al. (2007) investigate the link between family's social capital and family firms' social capital and provide a conceptual framework to analyze family firms from a social capital perspective. Research in the accounting field has shown that the social capital of board members influences on firm's future performance and financial reporting quality (e.g., Horton, Millo, and Serafeim 2012; Carrera, Carmona, and Sohail 2017). Future accounting research could investigate how family firms' social capital, family's social capital and the interaction of both influence on the control mechanisms for financial reporting.

Lastly, our literature review shows that there are examples of accounting studies going beyond the "traditional" approach and exploring accounting issues in family firms through the lenses of the institutional theory (Bernadich 2015; Mengoli and Pazzaglia 2017) and the institutional entrepreneurship theory (Baños-Sanchez Matamoros et al. 2014). We encourage accounting researchers to further explore the opportunities brought by alternative theoretical approaches. For example, consider the insights of systems theory (e.g., Frank et al. 2010), the social exchange theory (Daspit et al. 2015) or a combination of theoretical approaches (e.g., Vallejo 
2011; Che and Langli 2015; Le Breton-Miller et al. 2015), all of which have been proved valid to examine issues arising in the context of family businesses. ${ }^{11}$

\subsection{Empirical Challenges - Opportunities}

As shown in the previous sections, most studies on accounting and family firms are empirical and quantitative. This trend is observed in other areas such as general management and business. ${ }^{12}$ In accounting, most studies rely on archival data, typically information from the annual reports, and apply statistical techniques such as regression analysis. Besides the problems related to the reliability of data and missing information, particularly relevant in the case of small-and-medium family firms and in privately-held family firms (Stewart and Miner 2011), researchers face the challenge of defining what "family business" means and how to operationalize the construct as explained in Section Defining Family Firms. Prencipe et al. (2014, 367-368) discuss this issue in detail and highlight how the focus over the past few years have shifted from dichotomous definitions to identify family and non-family firms to more articulated definitions, which allow to consider the heterogeneity within family firms. As stressed by prior studies (e.g., Songini et al. 2013) there is a clear need to pay attention to within-group differences of family business. Steier et al. (2015) refer to the importance of differentiate the controlling family as a "business family" and as a "family business": in the former, the family owns one or more businesses and these businesses may change over time; in the later, the family owns the business and it wants the next generation to take over. Another possibility is to use continue variables to measure family involvement, experience and power,

\footnotetext{
${ }^{11}$ Vallejo (2011) proposes a model to measure the culture of family firms that integrates propositions derived from the general system theory, socialization theory, neoinstitutional theory, transformational leadership theory, learning theory, field theory, and group dynamics theory. Le Breton-Miller et al. (2015) combines agency theory, behavioral agency perspectives, and the RBV of the firm.

12 See Evert et al. (2016) for a review of empirics in family business research and Fletcher, De Massis, and Nordqvist (2016) for a review of qualitative research in this area.
} 
as suggested by Astrachan et al. (2002) and Klein et al. (2005). Differences within family firms may influence on accounting decisions, as some prior studies have shown (e.g. Corten et al. (2017) in the case of auditing). Future research could further explore the heterogeneity of family firms and to what extent it influences on accounting decisions. For example, using content analysis of organizational narratives (e.g., Kothari, Li, and Short 2009), researchers could explore the disclosures of different types of family firms, their drivers and their outcomes.

On this review, few papers rely on data from questionnaires and surveys (Samuelsson et al. 2016; Cesaroni and Sentuti 2017; Collin et al. 2017; Corten et al. 2017), none of them in the area of financial accounting. There is an opportunity in the use of these techniques for measuring dimensions related to family power, influence or control through, for example, psychometric instruments which could be used in studies assessing the financial reporting quality of the firm and/or accounting choices of family firms. These tools also allow the researcher to collect data on demographic characteristics (e.g., education, social ties and age of the founders) which may help to capture the "family effect". Berrone et al. (2012) provide some insights about how to operationalize and measure the different dimensions included in the concept of SEW using data collected from surveys, content analysis or experiments. This data could be used to test the influence of the dimension "family identity" on financial reporting quality (Gomez-Mejia et al. 2014). Surveys could also be used to collect data for multilevel analysis, exploring the impact of accounting at a firm level and at an individual level -for example, studies examining management control systems at family firms and/or about the perception of auditing.

Another area that could be explored further is the use of panel data and longitudinal analysis (Benavides-Velasco, Guzmán-Parra, and Quintana-García 2011). As highlighted by Evert et al. 
(2016), time is a key component in family businesses. Most prior research on accounting and family firms does not consider explicitly the time dimension. Future research should contemplate the possibility of developing longitudinal analysis and panel data, in line with the suggestions for future research examining family firms in other fields (Evert et al. 2016; Benavides-Velasco et al. 2011).

As highlighted by prior reviews, there is a lack of experimental and decision-making studies in accounting and family firms. Trotman and Trotman (2010) provide an in-depth discussion of the stream of research in auditing based on conceptual frameworks developed within psychology to evaluate, among other issues, the quality of audit judgments, the factors that influence auditors' judgment performance and the cognitive processes used by auditors. They highlight the potential of this approach to get a better understanding of the differences in the audit task, the auditor and her/his attributes and the interaction between the auditor and other stakeholders between family and nonfamily businesses, and how these differences could potential influence on auditors' judgment. Like in the area of auditing, researchers examining managerial accounting issues at family firms could also benefit from adopting conceptual frameworks developed within family psychology to better understand what actually being a "family business" makes in the implementation of management accounting practices and control systems.

As pointed out by prior studies (e.g., Evert et al. 2016, Fletcher et al. 2016), there are significant opportunities for qualitative studies adopting methods such as ethnographies or case studies that allow researchers to better understand the unique characteristics of family businesses. Furthermore, compared to quantitative methods, qualitative approaches offer the researcher the possibility to "build a holistic perspective of the phenomenon under study and to observe the 
development of a phenomenon over time" (Fletcher et al. 2016, 18). Case studies are the most used qualitative methodology in family business research so far (De Massis and Kotlar $2014^{13}$ ). While they are widely used by accounting historians and researchers exploring management accounting practices, its use in accounting research in family firms is still limited. Case studies could be used to develop research on management accounting and control, an area where much more work needs to be done (e.g., Songini et al. 2013; Prencipe et al. 2014). They could also be used to investigate further the cross-country differences in the adoption and implementation of management accounting practices and how control and management accounting systems influence on succession in different settings. Special interest could be paid to research in accounting practices of family firms in developing countries were these firms may play a significant role in the economic development. Case studies can be fruitful for the analysis of the drivers and consequences of professionalization in family firms as well as for the analysis the role of accounting in family business failure and survival. They could also be applied to investigation of family leaders' biographies to assess their role in fostering or hindering accounting change (e.g., Parker 2014).

Finally, we should also consider the possibility of using mixed methods, combining quantitative and qualitative approaches (e.g., Björnberg and Nicholson 2012).

\section{Closing Remarks}

This paper reviews research on accounting in family firms. Overall, this study and prior literature reviews show that research on accounting in family firms has been dominated by accounting scholars with expertise in financial accounting interested in issues such as financial

\footnotetext{
${ }^{13}$ De Massis and Kotlar (2014) provide good guidelines on how to use case studies in family business research.
} 
reporting quality, earnings management and accounting policy choices from an agency perspective. Most of these studies provide insights about to what extent the financial reporting practices of family firms differ from those of non-family firms. We observe an increasing interest in family firms by researchers specialized in auditing as well as management accounting and control. Interestingly, over time accounting researchers seems to be more and more open to adopt alternative theoretical approaches beyond the agency theory framework, as shown by recent studies using the SEW approach. In this study, we include the contributions of accounting history to family business research, an area neglected in prior literature reviews. The studies reviewed show how fruitful can be a historical perspective to understand the role of accounting and accountants in the survival and failure of family firms as well as understanding their role in the development of accounting and auditing in society.

The interaction between accountants and researchers from other areas of knowledge related to family firms such as management and economics can be particularly rewarding. An interdisciplinary approach to the study of family firms, bringing together researchers from different disciplines, could help to overcome some of the current challenges of studies on family firms and develop some of the ideas presented in this review.

\section{References}

Achleitner, Ann-Kristin, Nina Günther, Christoph Kaserer, and Gianfranco Siciliano. 2014. "Real Earnings Management and Accrual-based Earnings Management in Family Firms.” European Accounting Review 23 (3): 431-461.

Ali, Ashiq, Tai-Yuan Chen, and Suresh Radhakrishnan. 2007. "Corporate Disclosure by Family Firms." Journal of Accounting and Economics 44 (1/2): 238-286.

Álvarez-Dardet, Concha, and Mariló Capelo. 2003. "Contractual Relationships and Accounting Change: the Case of Aguera Wholesalers, 1770-1835." Accounting History 8 (1): 61-88. 
Anderson, Ronald C., and David M. Reeb. 2003. "Founding-family Ownership and Firm Performance: Evidence from the S\&P 500.” Journal of Finance 58 (3): 1301-1328.

Arregle, Jean-Luc, Michael A. Hitt, David G. Sirmon, and Philippe Very. 2007. "The Development of Organizational Social Capital: Attributes of Family Firms." Journal of Management Studies 44 (1): 73-95

Astrachan, Joseph H., Sabine B. Klein, and Kosmas X. Smyrnios. 2002. "The F-PEC Scale of Family Influence: A Proposal for Solving the Family Business Definition Problem.” Family Business Review 15 (1): 45-58.

Auditing Standard No. 5. 2007. An Audit of Internal Control Over Financial Reporting That Is Integrated with an Audit of Financial Statements. Issued by the Public Company Accounting $\begin{array}{llllll}\text { Oversight } & \text { Body } & \text { (PCAOB). Accessed }\end{array}$ https://pcaobus.org/Standards/Auditing/pages/auditing_standard_5.aspx

Baños-Sánchez Matamoros, Juan, Pedro Araujo-Pinzón, and Concha Álvarez-Dardet Espejo. 2014. "Management Accounting Change and Agency in Embedded Situations." Spanish Journal of Finance and Accounting 43 (3): 241-265.

Bardhan, Indranil, Shu Lin, and Shu-Ling Wu. 2015. "The Quality of Internal Control over Financial Reporting in Family Firms.” Accounting Horizons 29 (1): 41-60.

Barney, Jay. 1991. "Firm Resources and Sustained Competitive Advantage." Journal of Management 17 (1): 99-120.

Barroso, Raúl, Chiraz B. Ali, and Cedric Lesage. 2016. "Blockholders' Ownership and Audit Fees: The Impact of the Corporate Governance Model." European Accounting Review (September 23,2016). doi:10.1080/09638180.2016.1243483.

Benavides-Velasco, Carlos A., Vanesa F. Guzmán-Parra, and Cristina Quintana-García. 2011. "Evolución de la Literatura sobre Empresa Familiar Como Disciplina Científica." Cuadernos de Economía y Dirección de la Empresa 14 (2): 78-90.

Bernadich, Marc. 2015. "The Creation of Family Firms in Catalonia: An Institutional Approach.” PhD diss., Universitat Autònoma de Barcelona.

Berrone, Pascual, Cristina Cruz, and Luis R. Gomez-Mejia. 2012. "Socioemotional Wealth in Family Firms: Theoretical Dimensions, Assessment Approaches, and Agenda for Future Research." Family Business Review 25:258-279.

Bhaumik, Sumon K., and Andros Gregoriou. 2010. "Family' Ownership, Tunneling and Earnings Management: A Review of the Literature.” Journal of Economic Surveys 24 (4): 705-729.

Björnberg, Åsa, and Nigel Nicholson. 2012. "Emotional Ownership: The Next Generation's Relationship with the Family Firm." Family Business Review 25:374-390. 
Bravo, Rafael, Jesús Cambra, Edgar Centeno, and Iguácel Melero. 2017. "The Importance of Brand Values in Family Business." Journal of Evolutionary Studies in Business 2 (2), (forthcoming).

Camfferman, Kees, and Stephen A. Zeff. 2003. “The Apotheosis of Holding Company Accounting': Unilever's Financial Reporting Innovations from the 1920s to the 1940s." Accounting, Business and Financial History 13 (2): 171-206.

Carey, Peter, Roger Simnett, and George Tanewski. 2000. "Voluntary Demand for Internal and External Auditing by Family Businesses.” Auditing: A Journal of Practice and Theory 19 (Supplement): $37-51$.

Carnegie, Garry D., and Christopher J. Napier. 2012. “Accounting's Past, Present and Future: The Unifying Power of History.” Accounting, Auditing \& Accountability Journal 25 (2): 328-369.

Carrera, Nieves, Salvador Carmona, and Tashfeen Sohail. 2017. “Audit Committees' Social Capital and Financial Reporting Quality." Accounting and Business Research (May 16,2017): 1-40. doi:10.1080/00014788.2017.1299617.

Cascino, Stefano, Amadeo Pugliese, Donata Mussolino, and Chiara Sansone. 2010. "The Influence of Family Ownership on the Quality of Accounting Information." Family Business Review 23 (3): 246-265.

Casillas, José C., M. Concepción López, Ángel Meroño, Aleix Pons, and Raimon Baiges. 2015. La Empresa Familiar en España (2015). (J. Corona, Ed.). Barcelona: Instituto de la Empresa Familiar. Accessed June 13, 2017. http://www.iefamiliar.com/publicaciones/la-empresa-familiaren-espana-2015

Cesaroni, Francesca M., and Annalisa Sentuti. 2017. “Accountants' Role in the Management of Succession: Empirical Evidence from Italy.” Journal of Family Business Management 6 (3): 270290.

Che, Limei, and John C. Langli. 2015. "Governance Structure and Firm Performance in Private Family Firms." Journal of Business Finance \& Accounting 42 (9-10): 1216-1250

Chen Qiu, Shujun Ding, Zhenyu Wu, and Fan Yang. 2016. "Family Control, International Accounting Standards, and Access to Foreign Banks: Evidence from International Entrepreneurial Firms.” Journal of Small Business Management 54 (2): 598-621.

Chen, Charles J. P., and Bikki Jaggi. 2000. "Association between Independent Non-Executive Directors, Family Control and Financial Disclosures in Hong Kong." Journal of Accounting and Public Policy 19 (4/5): 285-310.

Chen, Shuping, Xia Chen, and Qiang Cheng. 2008. "Do Family Firms Provide More or Less Voluntary

Disclosure?" Journal of Accounting Research 46 (3): 499-536. 
Chen, Shuping, Xia Chen, and Qiang Cheng. 2014. "Conservatism and Equity Ownership of the Founding Family." European Accounting Review 23 (3): 403-430.

Chenhall, Robert H. 2003. "Management Control Systems Design within its Organizational Context: Findings from Contingency-Based Research and Directions for the Future." Accounting, Organisations and Society 28: 127-168.

Chi, Ching W., Ken Hung, Hui W. Cheng, and Pang T. Lieu. 2015. "Family Firms and Earnings Management in Taiwan: Influence of Corporate Governance.” International Review of Economics \& Finance 36:88-98.

Chrisman, James J., Jess H. Chua, and Pramodita Sharma. 2005. "Trends and Directions in the Development of a Strategic Management Theory of the Family Firm.” Entrepreneurship Theory and Practice 29 (5): 555-576.

Chrisman, James J., Jess H. Chua, and Reginald A. Litz. 2004. "Comparing the Agency Costs of Family and Non-Family Firms: Conceptual Issues and Exploratory Evidence.” Entrepreneurship Theory and Practice 28 (4): 335-354.

Chua, Jess H., James J. Chrisman, and Pramodita Sharma. 1999. "Defining the Family Business by Behavior." Entrepreneurship Theory and Practice 23 (4): 19-39.

Chua, Jess H., James J. Chrisman, Lloyd P. Steier, and Sabine B. Rau. 2012. "Sources of Heterogeneity in Family Firms: An Introduction.” Entrepreneurship Theory and Practice 36 (6): 1103-1113.

Collin, Sven-Olof Y., Jenny Ahlberg, Karin Berg, Pernilla Broberg, and Amelie Karlsson. 2017. "The Auditor as Consigliere in Family Firm." Journal of Family Business Management 7 (1): 2-20.

Corten, Maarten, Tensie Steijvers, and Nadine Lybaert. 2015. "The Demand for Auditor Services in Wholly Family-owned Private Firms: The Moderating Role of Generation." Accounting and Business Research 45 (1): 1-26.

Corten, Maarten, Tensie Steijvers, and Nadine Lybaert. 2017. "The Effect of Intrafamily Agency Conflicts on Audit Demand in Private Family Firms: The Moderating Role of the Board of Directors." Journal of Family Business Strategy 8:13-28.

Cruz, Cristina, Claudia Imperatore, and Luis R. Gomez-Mejia. 2015. "Family Firms, Income smoothing and Financial Crisis: Evidence from European Countries." Working Paper, Academy of Management. Annual Meeting Proceedings. Accessed February 23, 2017. http://proceedings.aom.org/content/2015/1/16811.short.

Daspit, Joshua J., Daniel T. Hot, James J. Chrisman, and Rebecca G. Long. 2015. "Examining Family Firm Succession from a Social Exchange Perspective: A Multiphase, Multistakeholder Review." Family Business Review 29 (1): 44-64. 
Davis, James H., F. David Schoorman, and Lex Donaldson. 1997. "Towards a Stewardship Theory of Management." Academy of Management Review 22 (1): 20-47.

De Massis, Alfredo, and Josip Kotlar. 2014. "The Case Study Method in Family Business Research: Guidelines for Qualitative Scholarship.” Journal of Family Business Strategy 5: 15-29.

Dechow, Patricia, Weili Ge, and Catherine Schrand. 2010. "Understanding Earnings Quality: A Review of the Proxies, their Determinants and their Consequences." Journal of Accounting and Economics 50 (2-3): 344-401.

DeFond, Mark, and Jieying Zhang. 2014. "A Review of Archival Auditing Research.” Journal of Accounting and Economics 58 (2/3): 275-326.

Dekker, Julie, Nadine Lybaert, Tensie Steijvers, and Benoît Depaire. 2015. "The Effect of Family Business Professionalization as a Multidimensional Construct on Firm Performance." Journal of Small Business Management 53 (2): 516-538.

Dhaliwal, Dan S., Gerald L. Salamon, and E. Dan Smith. 1982. "The Effect of Owner versus Management Control on the Choice of Accounting Methods." Journal of Accounting and Economics 4 (1): 41-53.

Diéguez-Soto, Julio, Pilar López-Delgado, and Alfonso A. Rojo-Ramírez. 2015. "Identifying and Classifying Family Businesses." Review of Managerial Science 9 (3): 603-634.

Ding, Shujun, Baozhi Qu, and Zili Zhuang. 2011. "Accounting Properties of Chinese Family Firms." Journal of Accounting, Auditing and Finance 26 (4): 623-640.

Duréndez, Antonio, Antonia Madrid-Guijarro, and Domingo García-Pérez-de-Lema. 2011. "Innovative Culture, Management Control Systems and Performance in Small and Medium-sized Spanish Family Firms.” Innovar 21 (40): 137-153.

Efferin, Sujoko, and Monika S. Hartono. 2015. "Management Control and Leadership Styles in Family Business: An Indonesian Case Study.” Journal of Accounting \& Organizational Change 11 (1): 130-159.

European Commission. 2017. Family Business. Accessed February 25, 2017. https://ec.europa.eu/growth/smes/promoting-entrepreneurship/we-work-for/family-business es. European Commission. 2009. Final Report of the Expert Group. Overview of Family-Business Relevant Issues: Research, Networks, Policy Measures and Existing Studies. European Commission. Directorate-General for Enterprise and Industry.

Evert, Robert E., John A. Martin, Michael S. McLeod, and G. Tyge Payne. 2016. "Empirics in Family Business Research: Progress, Challenges, and the Path Ahead." Family Business Research 29 (1): $17-43$. 
Fernández-Pérez, Paloma, and Nuria Puig. 2013. "The Emergence of Family Business Studies: A Historical Approach to Pioneering Centers, Scholars and Ideas." In The Endurance of Family Business. A Global Overview, edited by Paloma Fernández-Pérez and Andrea Colli, 13-32. New York: Cambridge University Press.

Fletcher, Denise, Alfredo De Massis, and Mattias Nordqvist. 2016. "Qualitative Research Practices and Family Business Scholarship: A Review and Future Research Agenda." Journal of Family Business Strategy 7 (1): 8-25.

Fletcher, Denise, Leif Melin, and Alberto Gimeno. 2012. "Culture and Values in Family Business - A Review and Suggestions for Future Research.” Journal of Family Business Strategy 3 (3): 127131.

Fournès-Dattin, Christine. 2014. "The Practice of Statutory Auditing in France (1867-1935): The Case of Pont-à-Mousson and Saint-Gobain Companies.” Accounting History 19 (3): 351-368.

Frank, Hermann, Manfred Lueger, Lavinia Nosé, and Daniela Suchy. 2010. "The Concept of "Familiness." Literature Review and Systems Theory-based Reflections." Journal of Family Business Strategy 1 (3): 119-130.

Ghosh, Aloke, and Charles Y. Tang. 2015. "Assessing Financial Reporting Quality of Family Firms:

The Auditors' Perspective." Journal of Accounting and Economics 60:95-116.

Giovannoni, Elena, Maria P. Maraghini, and Angelo Riccaboni. 2011. "Transmitting Knowledge across Generations: The Role of Management Accounting Practices.” Family Business Review 24 (2): $126-150$.

Golden, Joanna, and Mark J. Kohlbeck. 2017. "The Influence of Family Firm Dynamics on Voluntary Disclosures." Advances in Accounting 37 (2): 111-121.

Gomez-Mejia, Luis R., Cristina Cruz, and Claudia Imperatore. 2014. "Financial Reporting and the Protection of Socioemotional Wealth in Family-controlled Firms." European Accounting Review 23 (3): 387-402.

Gomez-Mejia, Luis R., Cristina Cruz, Pascual Berrone, and Julio De Castro. 2011. "The Bind that Ties: Socioemotional Wealth Preservation in Family Firms." The Academy of Management Annals 5 (1): 653-707.

Gomez-Mejia, Luis R., Theresa M. Welbourne, and Robert M. Wiseman. 2000. "The Role of Risk Taking and Risk Sharing under Gainsharing." Academy of Management Review 25 (3): 492-507. Gopalan, Radhakrishnan, and Sudarshan Jayaraman. 2012. "Private Control Benefits and Earnings Management: Evidence from Insider Controlled Firms.” Journal of Accounting Research 50 (1): 117-157. 
Greco, Giulio, Silvia Ferramosca, and Marco Allegrini. 2015. "The Influence of Family Ownership on Long-Lived Asset Write-Offs.” Family Business Review 28 (4): 355-371.

Habbershon, Timothy G., and Mary L. Williams. 1999. "A Resource-based Framework for Assessing the Strategic Advantages of Family Firms." Family Business Review 12 (1): 1-25.

Healy, Paul M., and James M. Wahlen. 1999. "A Review of the Earnings Management Literature and its Implications for Standard Setting." Accounting Horizons 13:365-383.

Helsen, Zoe, Nadine Lybaert, Tensie Steijvers, Raf Orens, and Julie Dekker. 2017. "Management Control Systems in Family Firms: A Review of the Literature and Directions for the Future." Journal of Economic Surveys 31 (2): 410-435.

Hiebl, Martin R.W., Birgit Feldbauer-Durstmüller, and Christine Duller. 2013. "The Changing Role of Management Accounting in the Transition from a Family Business to a Non-Family Business." Journal of Accounting \& Organizational Change 9 (2): 119-154.

Hiebl, Martin R.W., Christine Duller, and Birgit Feldbauer-Durstmüller. 2012. "Do Management Accountants Play a Different Role in Family Firms? Empirical Evidence on Management Accountants' Qualification and Roles in Family and Non-Family Firms." International Journal of Business Research 12 (2): 94-103.

Ho, Joanna L., and Fei Kang. 2013. "Auditor Choice and Audit Fees in Family Firms: Evidence from the S\&P 1500." Auditing: A Journal of Practice \& Theory 32 (4): 71-93.

Hope, Ole-Kristian, John C. Langli, and Wayne B. Thomas. 2012. "Agency Conflicts and Auditing in Private Firms." Accounting, Organizations and Society 37 (7): 500-517.

Horton, Joanne, Yuval Millo, and George Serafeim. 2012. "Resources or Power? Implications of Social Networks on Compensation and Firm Performance.” Journal of Business Finance and Accounting 39 (3/4): 399-426.

Jara-Bertin, Mauricio, and Félix J. López-Iturriaga. 2014. "Earnings Management and the Contest to the Control: An International Analysis of Family-owned Firms." Spanish Journal of Finance and Accounting 43 (4): 355-379.

Jensen, Michael C., and William H. Meckling. 1976. "Theory of the Firm: Managerial Behavior, Agency Costs and Ownership Structure.” Journal of Financial Economics 3 (4): 305-360.

Jiraporn, Pornsit, and Peter J. DaDalt. 2009. "Does Founding Family Control Affect Earnings Management?" Applied Economics Letters 16 (2): 117-124.

Kang, Fei. 2014. "Founding Family Ownership and the Selection of Industry Specialist Auditors." Accounting Horizons 28 (2): 261-276. 
Khalil Samer, and Mohamad Mazboudi. 2016. "Client Acceptance and Engagement Pricing following Auditor Resignations in Family Firms." Auditing: A Journal of Practice \& Theory 35 (4): 137158.

Kininmonth, Kristen, and Sam McKinstry. 2007. "Stitching it up: Accounting and Financial Control at J \& P Coats Ltd, c1890-1960.” Accounting History 12 (4): 367-391.

Klein, Sabine B., Joseph H. Astrachan, and Kosmas X. Smyrnios. 2005. "The F-PEC Scale of Family Influence: Construction, Validation, and Further Implication for Theory." Entrepreneurship Theory and Practice 29 (3): 321-339.

KMU Forschung Austria. 2008. Overview of Family Business Relevant Issues. Contract No. 30-CE0164021/00-51 Final Report. Austrian Institute for SME Research: Vienna.

Kothari, S.P., Xu Li, and James E. Short. 2009. "The Effect of Disclosures by Management, Analysts, and Business Press on Cost of Capital, Return Volatility, and Analyst Forecasts: A Study Using Content Analysis." The Accounting Review 84 (5): 1639-1670.

Le Breton-Miller, Isabelle, Danny Miller, and Franck Bares. 2015. "Governance and Entrepreneurship in Family Firms: Agency, Behavioral Agency and Resource-based Comparisons." Journal of Family Business Strategy 6 (1): 58-62.

Leenders, Mark, and Eric Waarts. 2003. "Competitiveness and Evolution of Family Businesses: The Role of Family and Business Orientation.” European Management Journal 21 (6): 686-697.

Levy, Marc. 2009. "Control in Pyramidal Structures.” Corporate Governance: An International Review 17 (1): 77-89.

Lloyd-Jones, Roger, and Myrddin J. Lewis. 1994. "Personal Capitalism and British Industrial Decline: The Personally Managed Firm and Business Strategy in Sheffield, 1880-1920.” Business History Review 68(3): 364-411.

Lucas, Michael, Malcolm Prowle, and Glynn Lowth. 2013. Management Accounting Practices of (UK) Small-Medium-Sized Enterprises 9 (4). Accessed February 20, 2017. http://www.cimaglobal.com/Documents/Thought_leadership_docs/Management\%20and\%20fin ancial\%20accounting/ManagementAccountingPracticesOfSmall-Medium-SizedEnterprises.pdf

Ma, Liangbo, Shiguang Ma, and Gary Tian. 2017. "Corporate Opacity and Cost of Debt for Family Firms." European Accounting Review 26 (1): 27-59.

Madison, Kristen, Daniel T. Holt, Franz W. Kellermanns, and Annette L. Ranft. 2016. "Viewing Family Firm Behavior and Governance through the Lens of Agency and Stewardship Theories." Family Business Review 29 (1) 65-93. 
Martin, Geoffrey, Joanna Tochman-Campbell, and Luis R. Gomez-Mejia. 2016. "Family Control, Socioemotional Wealth and Earnings Management in Publicly Traded Firms." Journal of Business Ethics 133:453-469.

Martínez-Ferrero, Jennifer, Lázaro Rodríguez-Ariza, and Manuel Bermejo-Sánchez. 2015. "Is Family Ownership of a Firm Associated with the Control of Managerial Discretion and Corporate Decisions?" Journal of Family Business Management 6 (1):23-45.

Mathias, Peter. 1993. "Business History and Accounting History: a Neighborly Relationship." Accounting, Business \& Financial History 3 (3): 253-273.

Matthews, Derek. 2006. "From Ticking to Clicking: Changes in Auditing Techniques in Britain from 19th Century to the Present." Accounting Historians Journal 33 (2): 63-102.

McWatters, Cheryl S. 2002. "A Counter-Example in the Development of Great Lakes Shipping: The Case of Kingston Shipping Company Limited.” Accounting History 7 (2): 59-92.

Mengoli, Stefano, and Federica Pazzaglia. 2017. "Family Ownership and Earnings Quality: Evidence from Different Institutional Environments." Working Paper, SSRN, March 13, 2017. https://ssrn.com/abstract=2932069.

Moilanen, Sinikka. 2008. "The Role of Accounting in the Management Control System: A Case Study of a Family-led Firm." Qualitative Research in Accounting \& Management 5 (3): 165-183.

Moores, Ken, and Carlo Salvato. 2009. "Call for Papers: Family Business Review - Special Issue. Accounting in Family Firms.” Family Business Review 22 (2): 185-186.

Muttakin, Mohamad B., Arifur Khan, and Ataur R. Belal. 2015. "Intellectual Capital Disclosures and Corporate Governance: An Empirical Examination.” Advances in Accounting 31 (2): 219-227.

Nagar, Neerav, and Kaustav Sen. 2016. "How Does Regulation Affect the Relation Between Family Control and Reported Cash Flows? Comparative Evidence from India and the United States." Corporate Governance: An International Review 24 (5): 490-508.

Neubauer, Herbert, Stefan Mayr, Birgit Feldbauer-Durstmüller, and Christine Duller. 2012. "Management Accounting Systems and Institutionalization in Medium-sized and Large Family Businesses - Empirical Evidence from Germany and Austria." European Journal of Management 12 (2): 14-69.

Niehaus, Gregory R. 1989. "Ownership Structure and Inventory Method Choice.” The Accounting Review 64 (2): 269-284.

Niskanen, Mervi, Jukka Karjalainen, and Jyrki Niskanen. 2010. "The Role of Auditing in Small, Private Family Firms: Is It About Quality and Credibility?” Family Business Review 23 (3): 230-245. 
Parker, Lee D. 2014. "Corporate Social Accountability through Action: Contemporary Insights from British Industrial Pioneers." Accounting Organizations and Society 39 (8): 632-659.

Pazzaglia, Federica, Stefano Mengoli, and Elena Sapienza. 2013. "Earnings Quality in Acquired and Nonacquired Family Firms: A Socioemotional Wealth Perspective.” Family Business Review 26 (4): 374-386.

Pearson, Allison W., John C. Carr, and John C. Shaw. 2008. "Toward a Theory of Familiness: A Social Capital Perspective.” Entrepreneurship Theory and Practice 32 (6): 949-969.

Popp, Andrew. 2000. "Specialty Production, Personal Capitalism and Auditors' Reports: Mintons Ltd. 1870-1900." Accounting, Business \& Financial History 10 (3): 347-369.

Prencipe, Annalisa, and Sasson Bar-Yosef. 2011. "Corporate Governance and Earnings Management in Family-Controlled Companies.” Journal of Accounting Auditing and Finance 26 (2): 199-227.

Prencipe, Annalisa, Garen Markarian, and Lorenzo Pozza. 2008. "Earnings Management in Family Firms: Evidence from R\&D Cost Capitalization in Italy." Family Business Review 21 (1): 71-88. Prencipe, Annalisa, Sasson Bar-Yosef, and Henri C. Dekker. 2014. "Accounting Research in Family Firms: Theoretical and Empirical Challenges." European Accounting Review 23 (3): 361-385.

Prencipe, Annalisa, Sasson Bar-Yosef, Pietro Mazzola, and Lorenzo Pozza. 2011. "Income Smoothing in Family Firm-Controlled Companies: Evidence from Italian Listed Companies." Corporate Governance: An International Review 19 (6): 529-546.

Razzaque, Rushdi M. R., Muhammad J. Ali, and Paul R. Mather. 2016. "Real Earnings Management in Family Firms: Evidence from an Emerging Economy.” Pacific-Basin Finance Journal 40:237250.

Robb, Alan J., Yvonne P. Shanahan, and Beverley R. Lord. 2006. "Ernest Adams Ltd: The Demise of a Family Business." Accounting History 11 (3): 357-379.

Salvato, Carlo, and Ken Moores. 2010. "Research on Accounting in Family Firms: Past Accomplishments and Future Challenges." Family Business Review 16 (3): 160-177.

Samuelsson, Joachim, Jim Andersén, Torbjörn Ljungkvist, and Christian Jansson. 2016. "Formal Accounting Planning in SMEs: The Influence of Family Ownership and Entrepreneurial Orientation.” Journal of Small Business and Enterprise Development 23 (3): 691-702.

Schulze, William S., Michael H. Lubatkin, and Richard N. Dino. 2002. "Altruism, Agency, and the Competitiveness of Family Firms." Managerial and Decision Economics 23 (4/5): 247-259.

Schulze, William S., Michael H. Lubatkin, and Richard N. Dino. 2003. "Toward a Theory of Agency and Altruism in Family Firms.” Journal Business Venturing 18 (4): 473-490.

Schulze, William S., Michael H. Lubatkin, Richard N. Dino, and Ann K. Buchholtz. 2001. "Agency Relationships in Family Firms." Organization Science 12 (2): 99-116. 
Senftlechner, Daniel, and Martin R.W. Hiebl. 2015. "Management Accounting and Management Control in Family Businesses: Past Accomplishments and Future Opportunities." Journal of Accounting \& Organizational Change 11 (4): 573-606.

Sharma, Pramodita. 2004. "An Overview of the Field of Family Business Studies: Current Status and Directions for the Future." Family Business Review 17 (1): 1-35.

Sirmon, David G., and Michael A. Hitt. 2003. "Managing Resources: Linking Unique Resources, Management and Wealth in Family Firms.” Entrepreneurship: Theory and Practice 27 (4): 339 358.

Songini, Lucrezia, and Luca Gnan. 2015. "Family Involvement and Agency Cost Control Mechanisms in Family Small and Medium-Sized Enterprises.” Journal of Small Business Management 53 (3): 749-779.

Songini, Lucrezia, Luca Gnan, and Teemu Malmi. 2013. "The Role and Impact of Accounting in Family Business.” Journal of Family Business Strategy 4: 71-83.

Sousa-Paiva, Inna, Isabel Costa-Lourenço, and Manuel Castelo-Branco. 2016. "Earnings Management in Family firms: Current State of Knowledge and Opportunities for Future Research." Review of Accounting and Finance 15 (1): 85-100.

Speckbacher, Gerhard, and Paul Wentges. 2012. "The Impact of Family Control on the Use of Performance Measures in Strategic Target Setting and Incentive Compensation: A Research Note." Management Accounting Research 23 (1): 34-46.

Srinidhi, Bin N., Shaohua He, and Michael Firth. 2014. "The Effect of Governance on Specialist Auditor Choice and Audit Fees in U.S. Family Firms.” Accounting Review 89 (6): 2297-2329.

Steier, Lloyd P., James J. Chrisman, and Jess H. Chua. 2015. "Governance Challenges in Family Businesses and Business Families.” Entrepreneurship Theory and Practice 39 (6): 1265-1280.

Stergiou, Konstantinos, Junaid Ashraf, and Shahzad Uddin. 2013. "The Role of Structure and Agency in Management Accounting Control Change of a Family Owned Firm: A Greek Case Study." Critical Perspectives on Accounting 24 (1): 62-73.

Stewart, Alex, and Anne S. Miner. 2011. "The Prospects for Family Business in Research Universities." Journal of Family Business Strategy 2 (1): 3-14.

Stockmans, Annelies, Nadine Lybaert, and Wim Voordeckers. 2010. "Socioemotional Wealth and Earnings Management in Private Family Firms.” Family Business Review 23 (3): 280-294.

Stockmans, Annelies, Nadine Lybaert, and Wim Voordeckers. 2013. "The Conditional Nature of Board Characteristics in Constraining Earnings Management in Private Family Firms." Journal of Family Business Strategy 4:84-93. 
Tong, Yen H. 2007. "Financial Reporting Practices of Family Firms.” Advances in Accounting 23:231261.

Trotman, Andrew J., and Ken T. Trotman. 2010. "The Intersection of Family Business and Audit Research: Potential Opportunities." Family Business Review 23 (3): 216-229.

Tsamenyi, Mathew, Irvan Noormansyah, and Shahzad Uddin. 2008. "Management Controls in Familyowned Businesses (FOBs): A Case Study of an Indonesian Family-owned University." Accounting Forum 32 (1): 62-74.

Uddin, Shahzad. 2009. "Rationalities, Domination and Accounting Control: A Case Study from a Traditional Society." Critical Perspectives on Accounting 20 (6): 782-794.

Vallejo, Manuel C. 2011. "A Model to Study the Organizational Culture of the Family Firm." Small Business Economics 36 (1): 47-64.

Vent, Glenn, and Ronald A. Milne. 2000. “Accounting Practices of the St. Joseph Lead Company: 18641900." Accounting, Business \& Financial History 10 (2): 97-128.

Simões-Vieira, Elisabete F. 2016. "Earnings Management in Public Family Firms under Economic Adversity." Australian Accounting Review 26 (2): 190-207.

Villalonga, Belen, and Raphael Amit. 2006. "How do Family Ownership, Control and Management Affect Firm Value?" Journal of Financial Economics 80:385-417.

Walker, Stephen P. 2009. "Structures, Territories and Tribes". In The Routledge Companion to Accounting History, edited by John R. Edwards and Stephen P. Walker, 11-29. New York: Routledge.

Wang, Dechun. 2006. "Founding Family Ownership and Earnings Quality." Accounting Review 44 (3): 619-656.

Weiss, Dan. 2014. "Internal Controls in Family-owned Firms." European Accounting Review 23 (3): 463-482.

Wiseman, Robert M., and Luis R. Gomez-Mejia. 1998. "A Behavioral Agency Model of Managerial Risk Taking." Academy of Management Journal 23 (1): 133-153.

Wright, Mike, and Franz W. Kellermanns. 2011. "Family Firms: A Research Agenda and Publication Guide." Journal of Family Business Strategy 2 (4): 187-198.

Yang, Mei-Ling. 2010. "The Impact of Controlling Families and Family CEOs on Earnings Management." Family Business Review 23 (3): 266-279.

This is an Open Access article distributed under the terms of the Creative Commons Attribution-Non-Commercial-No Derivatives License (http://creativecommons.org/licenses/by-nc-nd/4.0/), which permits non-comercial re-use and distribution, provided the original work is properly cited, and is not altered or transformed in any way. 
Appendix 1. Journals included in the Literature Reviews

\begin{tabular}{|c|c|c|c|c|c|c|c|c|}
\hline Journals & Acronym & 1 & 2 & 3 & 4 & 5 & 6 & 7 \\
\hline Abacus & $\mathrm{ABA}$ & & & & & & & $\mathrm{O}$ \\
\hline Academy of Management Journal & AMA & & & & & $\mathrm{O}$ & & $\mathrm{O}$ \\
\hline Academy of Management Review & AMR & & & & & $\mathrm{O}$ & & $\mathrm{O}$ \\
\hline Accounting and Business Research & $\mathrm{ABR}$ & & & & & & & $\mathrm{X}$ \\
\hline Accounting and Finance & $\mathrm{AF}$ & & & & & $\mathrm{O}$ & & \\
\hline Accounting Auditing and Accountability Journal & AAAJ & & & & & & & $\mathrm{O}$ \\
\hline Accounting Business and Financial History & $\mathrm{ABFJ}$ & & & & & & & $\mathrm{X}$ \\
\hline Accounting Forum & $\mathrm{AF}$ & & & & $\mathrm{X}$ & & & \\
\hline Accounting Historians Journal & AHJ & & & & & & & $\mathrm{X}$ \\
\hline Accounting History & AHIS & & & & & & & $\mathrm{X}$ \\
\hline Accounting History Review & AHISR & & & & & & & $\mathrm{O}$ \\
\hline Accounting Horizons & $\mathrm{AH}$ & $X^{*}$ & & $\mathrm{X}$ & & & & $\mathrm{X}$ \\
\hline Accounting Organizations and Society & $\mathrm{AOS}$ & $\mathrm{X}$ & & $\mathrm{X}$ & & $\mathrm{O}$ & & $\mathrm{O}$ \\
\hline Administrative Science Quarter & ASQ & & & & & $\mathrm{O}$ & & $\mathrm{O}$ \\
\hline Advances in Accounting & AA & $\mathrm{X}$ & & $\mathrm{X}$ & & & $\mathrm{X}$ & $\mathrm{X}$ \\
\hline Applied Economic Letters & AEL & $\mathrm{X}$ & & $\mathrm{X}$ & & & $\mathrm{X}$ & $\mathrm{O}$ \\
\hline Area & AREA & & & & $\mathrm{X}$ & & & \\
\hline Auditing: A Journal of Theory and Practice & AJPT & $\mathrm{X}$ & & $\mathrm{X}$ & & & & $\mathrm{X}$ \\
\hline CEFS Working Capital Series & CEFS & & $\mathrm{X}$ & & & & & $\mathrm{O}$ \\
\hline Contemporary Accounting Research & CAR & $\mathrm{X}$ & & & & $\mathrm{O}$ & & $\mathrm{O}$ \\
\hline Corporate Governance & CG & & $\mathrm{O}$ & & & & & \\
\hline Corporate Governance: An International Review & CGIR & $\mathrm{X}$ & & $\mathrm{X}$ & $\mathrm{X}$ & $\mathrm{O}$ & $\mathrm{X}$ & $\mathrm{X}$ \\
\hline Critical Perspectives on Accounting & $\mathrm{CPA}$ & & & $\mathrm{X}$ & $\mathrm{X}$ & & & $\mathrm{O}$ \\
\hline Economic and Industrial Democracy & EID & & & & $\mathrm{X}$ & & & \\
\hline Entrepreneurial Behaviour and Research & EBR & & & & $\mathrm{X}$ & & & \\
\hline Entrepreneurship: Theory and Practice & ETP & & & & & $\mathrm{X}$ & & \\
\hline European Accounting Review & EAR & & & $\mathrm{X}$ & & & $\mathrm{X}$ & $\mathrm{X}$ \\
\hline European Journal of Management & EJM & & & & $\mathrm{X}$ & & & \\
\hline European Management Journal & EMJ & & & & $\mathrm{X}$ & & & \\
\hline Family Business Review & FBR & $\mathrm{X}$ & $\mathrm{X}$ & $\mathrm{X}$ & $\mathrm{X}$ & & $\mathrm{X}$ & $\mathrm{X}$ \\
\hline International Business and Economics Research Journal & IBERJ & & $\mathrm{X}$ & & & & & \\
\hline International Journal of Accounting & IJA & $\mathrm{X}$ & & $\mathrm{X}$ & $\mathrm{X}$ & & & $\mathrm{O}$ \\
\hline International Journal of Accounting and Finance & IJAF & & & & $\mathrm{X}$ & & & \\
\hline International Journal of Business and Management & IJBM & & & & $\mathrm{X}$ & & & \\
\hline International Journal of Business Research & IJBR & & & & $\mathrm{X}$ & & & \\
\hline International Journal of Business Strategy & IJBSTRAT & & & & $\mathrm{X}$ & & & \\
\hline International Journal of Economics & IJE & & & & $\mathrm{X}$ & & & \\
\hline International Journal of Entrepreneurial Venturing & IJEV & & & & $\mathrm{X}$ & & & \\
\hline International Journal of Human Resource Management & IJHRM & & & & & $\mathrm{X}$ & & \\
\hline International Journal of Management and Enterprise Development & IJMED & & & & $\mathrm{X}$ & & & \\
\hline International Review of Economics and Finance & IREF & & & & & $\mathrm{X}$ & $\mathrm{X}$ & \\
\hline
\end{tabular}




\begin{tabular}{|c|c|c|c|c|c|c|c|c|}
\hline Journals & Acronym & 1 & 2 & 3 & 4 & 5 & 6 & 7 \\
\hline Journal of Accounting and Economics & JAE & $\mathrm{X}$ & $\mathrm{O}$ & $\mathrm{X}$ & & $\mathrm{O}$ & $\mathrm{X}$ & $\mathrm{X}$ \\
\hline Journal of Accounting and Organizational Change & JAOC & & & $\mathrm{X}$ & & & & $\mathrm{X}$ \\
\hline Journal of Accounting and Public Policy & JAPP & $\mathrm{X}$ & $\mathrm{O}$ & $\mathrm{X}$ & & $\mathrm{O}$ & & $\mathrm{O}$ \\
\hline Journal of Accounting Auditing and Finance & JAAF & $\mathrm{X}$ & $\mathrm{X}$ & $\mathrm{X}$ & & & $\mathrm{X}$ & $\mathrm{O}$ \\
\hline Journal of Accounting Literature & JAL & $\mathrm{X}$ & & & & & & $\mathrm{O}$ \\
\hline Journal of Accounting Research & JAR & $\mathrm{X}$ & & $\mathrm{X}$ & & $\mathrm{O}$ & $\mathrm{X}$ & $\mathrm{O}$ \\
\hline Journal of Business Ethics & JBE & & & & & $\mathrm{X}$ & & $\mathrm{X}$ \\
\hline Journal of Business Finance and Accounting & JBFA & $\mathrm{X}$ & & & & $\mathrm{O}$ & & $\mathrm{O}$ \\
\hline Journal of Business Research & JBR & & $\mathrm{O}$ & & & $\mathrm{X}$ & & \\
\hline Journal of Business Venturing & JBV & & $\mathrm{O}$ & & $\mathrm{X}$ & $\mathrm{X}$ & & \\
\hline Journal of Change Management & $\mathrm{JCM}$ & & & & $\mathrm{X}$ & & & \\
\hline Journal of Economic Surveys & JES & & $\mathrm{X}$ & & & $\mathrm{O}$ & & $\mathrm{X}$ \\
\hline Journal of Family Business Management & JFBM & & $\mathrm{X}$ & & & & & $\mathrm{X}$ \\
\hline Journal of Family Business Strategy & JFBS & & $\mathrm{X}$ & & & $\mathrm{X}$ & $\mathrm{X}$ & $\mathrm{X}$ \\
\hline Journal of Financial Economics & JFE & & $\mathrm{X}$ & & & $\mathrm{O}$ & & $\mathrm{O}$ \\
\hline Journal of International Accounting Auditing and Taxation & JIAAT & $\mathrm{X}$ & & $\mathrm{X}$ & & & & $\mathrm{O}$ \\
\hline Journal of Management Studies & JMS & & & & $\mathrm{X}$ & & & $\mathrm{O}$ \\
\hline Journal of Small Business and Enterprise Development & JSMED & $\mathrm{X}$ & & & & & & $\mathrm{X}$ \\
\hline Journal of Small Business Management & JSBM & $\mathrm{X}$ & $\mathrm{X}$ & $\mathrm{X}$ & $\mathrm{X}$ & $\mathrm{X}$ & & $\mathrm{X}$ \\
\hline Long Range Planning & LRP & & $\mathrm{O}$ & & & $\mathrm{O}$ & & \\
\hline Management Accounting Research & MAR & & $\mathrm{X}$ & $\mathrm{X}$ & $\mathrm{X}$ & $\mathrm{X}$ & & $\mathrm{O}$ \\
\hline Management Learning & ML & & & & $\mathrm{X}$ & & & \\
\hline Management Science & MS & & & & & $\mathrm{O}$ & & $\mathrm{O}$ \\
\hline Organizational Science & OS & & & & $\mathrm{X}$ & $\mathrm{X}$ & & $\mathrm{O}$ \\
\hline Qualitative Research in Accounting and Management & QRAM & & & & $\mathrm{X}$ & & & \\
\hline Quarterly Journal of Economics & QJE & & & & $\mathrm{X}$ & & & \\
\hline Review of Accounting and Finance & RAF & $\mathrm{X}$ & & & & & & $\mathrm{X}$ \\
\hline Review of Accounting Studies & RAS & $\mathrm{X}$ & & & & & & $\mathrm{O}$ \\
\hline Revista Innovar Journal & INNOVAR & & & & $\mathrm{X}$ & & & \\
\hline Science and Applied Research & SAR & & & & $\mathrm{X}$ & & & \\
\hline Small Business Economics & SBE & $\mathrm{X}$ & & & & & & $\mathrm{O}$ \\
\hline Southeast Asian Studies & SAS & & & & $\mathrm{X}$ & & & \\
\hline Spanish Journal of Finance and Accounting & SJFA & $\mathrm{X}^{*}$ & & & & & $\mathrm{X}$ & $\mathrm{X}$ \\
\hline The Academy of Management Annals & ACAMA & & & & & $\mathrm{X}$ & & \\
\hline The Accounting Review & TAR & $\mathrm{X}$ & $\mathrm{X}$ & & & $\mathrm{O}$ & & $\mathrm{X}$ \\
\hline
\end{tabular}

1: Salvato and Moore (2010); 2: Songini et al. (2013); 3: Prencipe et al. (2014); 4: Senftlechner and Hiebl (2015); 5: Helsen et al. (2017); 6: Sousa-Paiva et al. (2016); 7: Current study.

$\mathrm{X}=$ Journals considered in the search strategy of the review with positive outcome (at least one paper on accounting and family firms); $\mathrm{O}=$ journals included in the search strategy of the review but no outcome (when available). * Working Paper at the time of the review; published later on in the journal indicated. 